\title{
The source and transport of bioaerosols in the air: A review
}

\author{
Wenwen Xie ${ }^{1}$, Yanpeng Li $(\bowtie)^{1,3}$, Wenyan Bai ${ }^{1}$, Junli Hou ${ }^{1}$, Tianfeng Ma ${ }^{1}$, Xuelin Zeng ${ }^{1}$, Liyuan Zhang ${ }^{1,3}$, \\ Taicheng $\mathrm{An}^{2}$
}

1 School of Water and Environment, Chang'an University, Xi'an 710054, China

2 Guangdong Key Laboratory of Environmental Catalysis and Health Risk Control, School of Environment Science and Engineering, Institute of Environmental Health and Pollution Control, Guangdong University of Technology, Guangzhou 510006, China

3 Key Laboratory of Subsurface Hydrology and Ecological Effects in Arid Region (Ministry of Education), Chang'an University,

Xi'an 710054, China

\section{H I G H L I G H T S}

- Emission of microbe from local environments is a main source of bioaerosols.

- Regional transport is another important source of the bioaerosols.

- There are many factors affecting the diffusion and transport of bioaerosols.

- Source identification method uncovers the contribution of sources of bioaerosols.

\section{A R T I C L E I N F O}

Article history:

Received 1 July 2020

Revised 13 November 2020

Accepted 13 November 2020

Available online 17 December 2020

Keywords:

Bioaerosols

Diffusion

Source identification

Biogeography

\section{G R A P H C A B S T R A C T}

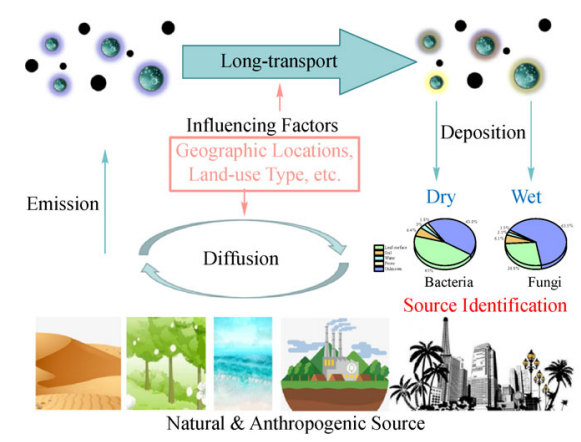

\section{A B S T R A C T}

Recent pandemic outbreak of the corona-virus disease 2019 (COVID-19) has raised widespread concerns about the importance of the bioaerosols. They are atmospheric aerosol particles of biological origins, mainly including bacteria, fungi, viruses, pollen, and cell debris. Bioaerosols can exert a substantial impact on ecosystems, climate change, air quality, and public health. Here, we review several relevant topics on bioaerosols, including sampling and detection techniques, characterization, effects on health and air quality, and control methods. However, very few studies have focused on the source apportionment and transport of bioaerosols. The knowledge of the sources and transport pathways of bioaerosols is essential for a comprehensive understanding of the role microorganisms play in the atmosphere and control the spread of epidemic diseases associated with them. Therefore, this review comprehensively summarizes the up to date progress on the source characteristics, source identification, and diffusion and transport process of bioaerosols. We intercompare three types of diffusion and transport models, with a special emphasis on a widely used mathematical model. This review also highlights the main factors affecting the source emission and transport process, such as biogeographic regions, land-use types, and environmental factors. Finally, this review outlines future perspectives on bioaerosols.

\section{Introduction}

Atmospheric aerosols are ubiquitous in the natural and

$\triangle$ Corresponding author

E-mail: liyanp01@chd.edu.cn

Special Issue-Bioaerosol, Environment and Health (Responsible Editors: Can Wang, Jungho Hwang, Jingkun Jiang \& Maosheng Yao) human environment. Bioaerosols are an important part of atmospheric aerosols. Bioaerosols, mainly including bacteria, fungi, and other microorganisms and biological substances, usually range from a nanometer to one-tenth of a millimeter in size (Matthias-Maser and Jaenicke, 1995; Smets et al., 2016). The largest mode diameter observed by fungal spores ranged from 1 to $30 \mu \mathrm{m}$, followed by that for bacteria $(0.2-0.8 \mu \mathrm{m})$. The smallest diameter are viruses about $0.3 \mu \mathrm{m}$. The size distribution of bioaerosols from 
animal and plant fragments was more different, ranging from 0.001 to $100 \mu \mathrm{m}$ (Poschl and Shiraiwa, 2015). Each year, different potential sources release large amounts of bioaerosols, which enter the atmosphere as particles (Burrows et al., 2009a; Burrows et al., 2009b; FröhlichNowoisky et al., 2016). Because of their small size and lightweight, bioaerosols can be transported over long distances through the wind, thus causing various acute and chronic diseases in humans, animals, and plants (Burrows et al., 2009b; Rodo et al., 2011; Tang et al., 2018). In addition to health effects, bioaerosols indirectly influence global climate change by absorbing and reflecting sunlight and promoting the formation of cloud droplets and ice crystals (Bauer et al., 2003; Burrows et al., 2009a; Fröhlich-Nowoisky et al., 2016).

Bioaerosols are attracting increasing levels of public attention in recent years. Figure 1 shows the number of articles published on bioaerosols has been rising over the past two decades. The central area of research on bioaerosols includes sampling and detection techniques, temporal and spatial characteristics, and the potential roles of bioaerosols in atmospheric chemistry and physics, climate, public health, and ecological systems (Jones and Harrison, 2004; Burrows et al., 2009b; Després et al., 2012; Bowers et al., 2013; Amato et al., 2015; FröhlichNowoisky et al., 2016; Kim et al., 2018; Xie et al., 2018). Bioaerosol control technology has become another active research area since the outbreak of airborne infectious diseases like the H1N1, SARS, and COVID-19 (Wei and Li, 2016; Ma et al., 2020). However, among the vast number of studies on bioaerosols, relatively few articles $(9.9 \% \pm 3.6 \%)$ have focused on the source and transport of bioaerosols. In order to better manage and control the transmission of pathogens via aerosols, it is also essential to investigate their sources and understand their modes of diffusion and transport.

Here, we review the progress of contemporary research

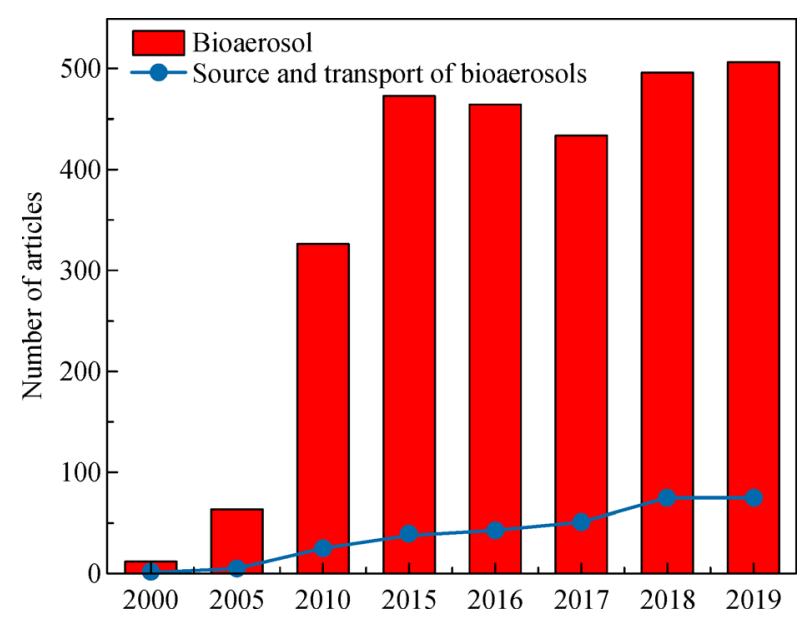

Fig. 1 Number of published articles on bioaerosols (The data from Web of Science). on the sources, diffusion, and transport mechanisms of bioaerosols. We also highlight the major environmental conditions that affect the diffusion and transport of bioaerosols as well as the techniques for the identification of the spatial location of microbial sources. Finally, we provide perspectives for future studies on the sources and transport pathways of microbes in the atmosphere based on current progress.

\section{Sources of bioaerosols}

Bioaerosols are ubiquitous in natural and working environments. Since air does not generally provide nutrients for microbial growth, the atmosphere acts only as a temporary residence rather than a source. As a result, the concentration and community composition of microbes in the air depend primarily on their emission sources. Bioaerosols are generated mainly from natural emissions and human activities, as shown in Fig. 2. The annual global budgets of bacteria, fungi, and pollen are reported to be 28.1, 186, and $84 \mathrm{Tg} /$ year respectively (Després et al., 2012). Water bodies, soil, plants, and anthropogenic activities are recognized as the primary sources of bacteria, fungi, viruses, and biologically derived compounds in the air (Bowers et al., 2011b; Bowers et al., 2013; SzylakSzydlowski et al., 2016).

\subsection{Natural sources}

Microorganisms existing in nature are usually released by carriers such as soil, water bodies, plant surfaces, and animals. Soil is the leading terrestrial natural source of bioaerosols. A large number of microbial communities thrive in soil (Veresoglou and Rillig, 2014) as the rich organic matter provides a natural medium for the growth of microorganisms. The estimated number of prokaryotes (both bacteria and archaea) in the desert and cultivated soils $\left(\sim 2 \times 10^{9}\right.$ cells $\left./ \mathrm{g}\right)$ is significantly larger than the forest soils $\left(4 \times 10^{7} \mathrm{cells} / \mathrm{g}\right)$ (William et al., 1998). It was estimated that the total number of bacteria emitted from land ranges from $1.5 \times 10^{23}$ to $3.5 \times 10^{24}$ cells/year (Burrows et al., 2009a). The action of wind releases a large amount of bioaerosols into the atmosphere. Núñez et al. (2019) found that most of the pathogenic bacteria originated from the soil in Madrid air. Likewise, Qi et al. (2020), more recently, observed that soil was one of the primary sources which released large amounts of fungi into the air. Rainfall can also facilitate the release of bioaerosols from the soil into the air. In the process of raindrops hitting the soil surface, the droplets containing soil bacteria are dispersed. It is reported that $0.01 \%$ of bacteria in soil could enter the atmosphere when a raindrop falls, and the total number of bacteria dispersed by raindrops can range from $1.2 \times 10^{22}$ to $8.5 \times 10^{23}$ cells/year (Joung et al., 2017).

In addition, natural water bodies such as rivers, lakes, 


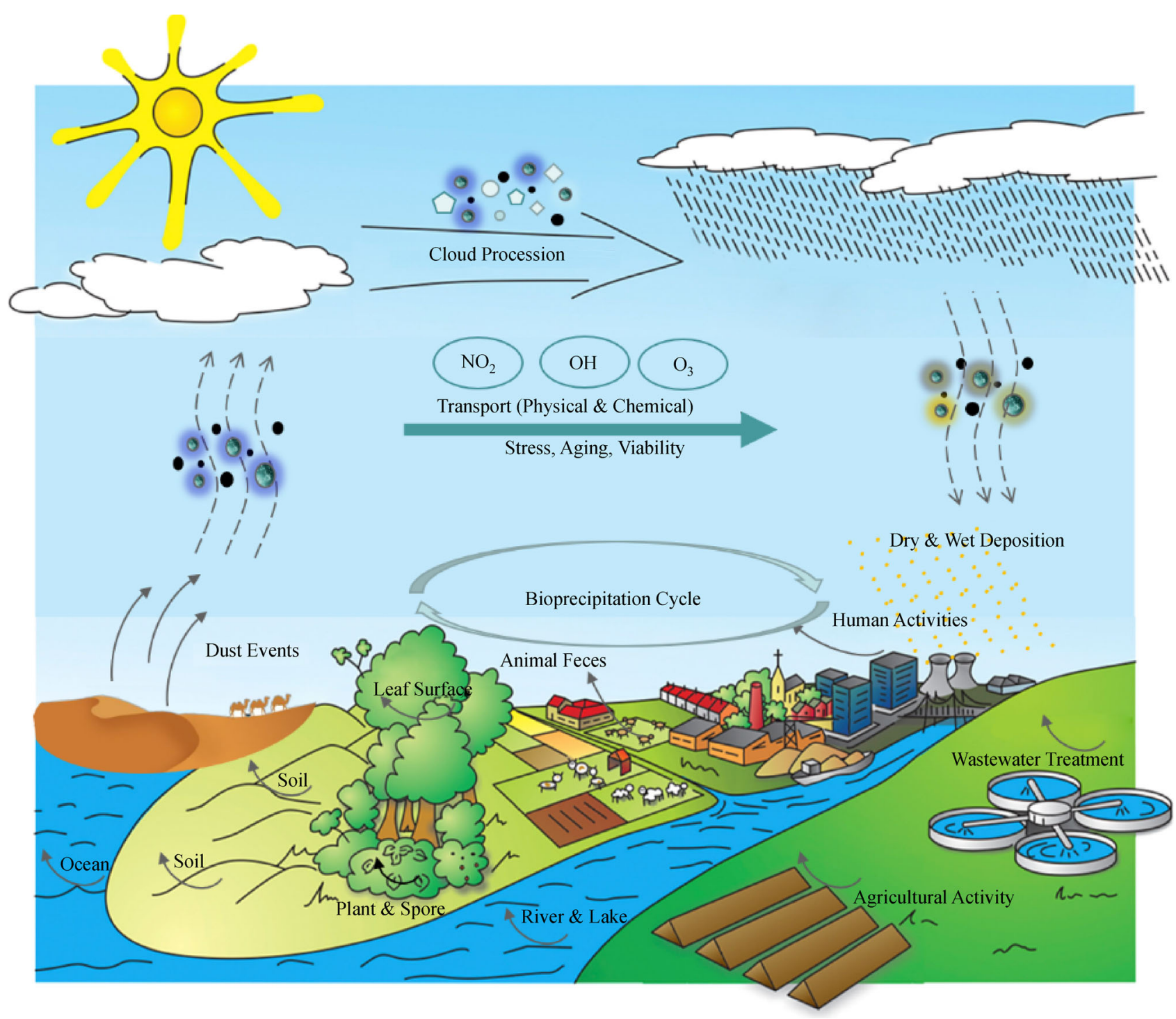

Fig. 2 Sources and transport of bioaerosols in nature. Adapted from Smets et al. (2016) and Fröhlich-Nowoisky et al. (2016).

and marine are also rich in various microorganisms. When the foams or bubble burst in water, a large amount of microorganisms would form and enter the atmosphere under the action of other external forces such as wind power and water power (Burrows et al., 2009b). It is reported that the concentration of prokaryotes over the East Sea was about $10^{4}-10^{5}$ cells $/ \mathrm{m}^{3}$ (Cho and Hwang, 2011). The airborne bacterial concentration over the Kuroshio Extension region of the northwest Pacific Ocean was of the order of $10^{4}-10^{5}$ cells $/ \mathrm{m}^{3}$, with high viability of $93 \%$ on average (Hu et al., 2017). The high loading of microorganisms over marine air was mainly released from the sea. So it is not surprising that the bacteria over Tokyo has long been affected by the seawater in the Tokyo Bay (Uetake et al., 2019).

Animals and plants usually release sensitized microorganisms in the air. Barberan et al. (2015a) found that indoor pets, especially cats and dogs, had a more significant contribution to indoor microflora. In rooms with cats and dogs, the abundance of 24 and 56 species of bacterial flora increased significantly, respectively (Barberan et al., 2015b). An increasing number of studies indicate that some animals could spread diseases to other animals or human beings through bioaerosols (Alves et al., 2010; Han et al., 2015; Hagerman et al., 2018; Bui et al., 2019). For instance, bats are considered as the natural reservoirs of viruses such as SARS-CoV, MERS-CoV, $\mathrm{NiV}, \mathrm{HeV}$, Ebola virus, and Marburg viruses. The viruses released by the bats spread through aerosols, causing diseases in intermediate hosts (horses, pigs, civets, or nonhuman primates) and later humans, or directly causing human infection (Han et al., 2015). Diseases from other animals, such as bird flu and foot-and-mouth disease, can also spread through aerosols, causing human illnesses and 
resulting in major public safety incidents (Hagerman et al., 2018; Bui et al., 2019).

Many microorganisms attached to the surface of plant leaves can migrate to the atmosphere under the action of wind. It is estimated that the bacterial community in the global plant circle consists of up to $10^{26}$ cells, with an average of $10^{6}-10^{7}$ cells per square centimeter of the leaf (Vorholt, 2012). Lymperopoulou et al. (2016) collected the air above the vegetation area and the adjacent nonvegetation area simultaneously. They found that the abundance of airborne bacteria and fungi of the vegetation area was 2-10 times higher than the non-vegetation site. Further, more than $50 \%$ of the bacteria in the downwind air samples were traced back to local plants. Pollen and fungal spores also come from various plants (Gopalakrishnan et al., 2019). While helping plants to carry out reproductive activities, pollen and fungal spores may cause an increase in the incidences of asthma and allergies (El Jarroudi et al., 2020).

The emissions of bioaerosols exist widely in nature, and their emission characteristics vary significantly with their sources. However, the mechanism of bioaerosol emission is not very well understood so far, and the available information on emission fluxes is also scarce. These limitations have immensely affected our understanding of the dynamics of microbes in the atmosphere and application of preventing their health risks. Therefore, relevant studies need to be strengthened further.

\subsection{Anthropogenic sources}

In addition to the airborne microorganisms from natural sources, human bodies and their daily activities can also release large amounts of bioaerosols, resulting in potential health risks, indoor and outdoor air pollution. Numerous kinds of bacteria live in different parts inside and outside the human body (Costello et al., 2009). Among them, about $10^{12}-10^{14}$ types of microbes live in the skin and the digestive tract of the human body (Luckey, 1972). Therefore, in an enclosed environment, human beings may be the largest artificial source of bioaerosols and can directly influence the structure and composition of the indoor microbial flora (Hospodsky et al., 2015).

Many studies have shown that the virus may be transmitted through aerosols released from patients (Lindsley et al., 2010; Wei and Li, 2016; Ma et al., 2020). When the patients breathe, speak, cough, and sneeze, they produce droplets or bioaerosols with a considerable amount of pathogenic microbes (seeing Fig. 3). Respiratory infections such as COVID-19, SARS, and influenza primarily spread through virusbearing liquid particles (droplets and aerosols) from the carriers' nose and mouth while breathing, coughing, and sneezing (Lindsley et al., 2010; Wei and Li, 2016; Asadi et al., 2020). The aerosols laden with viruses can stay in the air for hours, making people sick (Vejerano and Marr, 2018; van Doremalen et al., 2020). These bioaerosols have a relatively short propagation distance and prolonged survival times in indoor spaces, which poses a significant threat to human health (Ghanizadeh and Godini, 2018; Stockwell et al., 2019). Hence, it is particularly essential to attach importance to the study of indoor microbial sources (Kim et al., 2018).

Bioaerosols can be emitted from various working environments such as farms (hennery, pig farm, and cattle farm), landfills, wastewater treatment plants (WWTPs),



Fig. 3 The different transport routes of bioaerosols emitted by humans. Small water droplets $(<5 \mu \mathrm{m})$ are responsible for short-range airborne route, long-range airborne route, and indirect contact routes. Adapted from Wei and Li (2016). 
and other sites with frequent anthropogenic activities (Degois et al., 2017; Fraczek et al., 2017; Pagalilauan et al., 2018; White et al., 2019; Zhang et al., 2019). The airborne microbial characteristics at various working environments have been intensively examined (Table 1) to gain insights into the effects of bioaerosol emission on workers and residents near these sites.
Farm environments (poultry, pig farms and) release high concentrations of bioaerosols, ranging from $10^{3}$ to $10^{5}$ $\mathrm{CFU} / \mathrm{m}^{3}$ (culturable microorganisms) (Martin et al., 2010), which also affects the ambient aerosol concentrations (Skora et al., 2016; White et al., 2019). Theofel et al. (2020) showed that dust and bioaerosols moved a short distance into an almond orchard from an adjacent upwind

Table 1 Characteristics of bioaerosols released from various artificial sources

\begin{tabular}{|c|c|c|c|c|c|c|c|c|c|}
\hline \multirow{2}{*}{$\begin{array}{l}\text { Sampling } \\
\text { Site }\end{array}$} & \multirow[b]{2}{*}{ Basic Information } & \multirow{2}{*}{$\begin{array}{l}\text { Enumeration } \\
\text { Technique }\end{array}$} & \multicolumn{3}{|c|}{ Bacteria } & \multicolumn{3}{|c|}{ Fungi } & \multirow[b]{2}{*}{ Reference } \\
\hline & & & Conc. & $\begin{array}{c}\text { Dominant } \\
\text { Genera }\end{array}$ & $\begin{array}{c}\text { Pathogenic } \\
\text { Microorganism }\end{array}$ & Conc. & $\begin{array}{c}\text { Dominant } \\
\text { Genera }\end{array}$ & $\begin{array}{c}\text { Pathogenic } \\
\text { Microorganism }\end{array}$ & \\
\hline \multirow[t]{2}{*}{$\begin{array}{l}\text { Poultry } \\
\text { Farms }\end{array}$} & $\begin{array}{l}\text { Chicken number: } \\
6000 \\
\text { (China) }\end{array}$ & $\begin{array}{l}\text { Biochemical } \\
\text { Identification }\end{array}$ & - & $\begin{array}{c}\text { Brachybacter- } \\
\text { ium, Brevibacter- } \\
\text { ium, Salinicoc- } \\
\text { cus, Staphylo- } \\
\text { coccus, Faecali- } \\
\text { bacterium }\end{array}$ & $\begin{array}{c}\text { Enterococcus, } \\
\text { Parabacteroides, } \\
\text { Escherichia, } \\
\text { Megamonas }\end{array}$ & - & $\begin{array}{l}\text { Microascus, } \\
\text { Aspergillus, } \\
\text { Paraglomus }\end{array}$ & $\begin{array}{c}\text { Scopulariopsis, } \\
\text { Wallemia, } \\
\text { Fusarium }\end{array}$ & $\begin{array}{c}\text { Dai et al., } \\
2020\end{array}$ \\
\hline & $\begin{array}{l}\text { Bird number: } \\
8000-42000 \\
\text { (Poland) }\end{array}$ & $\begin{array}{l}\text { Cultivation } \\
\text { Microscopy }\end{array}$ & $\begin{array}{c}(3.2 \pm 5.0) \times \\
10^{9}(\mathrm{CFU} / \mathrm{g})\end{array}$ & $\begin{array}{c}\text { Bacillus, } \\
\text { Clostridia, } \\
\text { Corynebacter- } \\
\text { ium, } \\
\text { Enterobacter, }\end{array}$ & $\begin{array}{c}\text { Chlamydia } \\
\text { ornithosis, } \\
\text { Bacillus anthracis, } \\
\text { Mycoplasma spp., } \\
\text { Staphylococcus } \\
\text { aureus }\end{array}$ & $\begin{array}{c}(1.2 \pm 1.1) \times \\
10^{6}(\mathrm{CFU} / \mathrm{g})\end{array}$ & $\begin{array}{c}\text { Cladosporium, } \\
\text { Penicillium, } \\
\text { Aspergillus, } \\
\text { Alternaria }\end{array}$ & $\begin{array}{l}\text { Paecilomyces } \\
\text { variotii } \\
\text { A. fumigatus }\end{array}$ & $\begin{array}{c}\text { Skora } \\
\text { et al., } 2016\end{array}$ \\
\hline $\begin{array}{l}\text { Swine } \\
\text { Houses }\end{array}$ & $\begin{array}{l}\text { Swine number: } \\
140-480 \\
\text { (Republic of } \\
\text { Korea) }\end{array}$ & $\begin{array}{l}\text { Biochemical } \\
\text { Identification }\end{array}$ & - & - & - & - & $\begin{array}{l}\text { Clavaria, } \\
\text { Fusarium, } \\
\text { Rhodotorula, } \\
\text { Mortierella, }\end{array}$ & $\begin{array}{c}\text { Fusarium } \\
(10.8 \%)\end{array}$ & $\begin{array}{c}\text { Kumari } \\
\text { et al., } 2016\end{array}$ \\
\hline $\begin{array}{l}\text { Cattle Feed } \\
\text { Yards via }\end{array}$ & $\begin{array}{c}\text { Cattle number: } \\
\text { 20000-50000 } \\
\text { (USA) }\end{array}$ & $\begin{array}{l}\text { Biochemical } \\
\text { Identification }\end{array}$ & - & $\begin{array}{c}\text { Corynebacter- } \\
\text { ium, } \\
\text { Leptospira, } \\
\text { Clostridium, } \\
\text { Bacteroides, } \\
\text { Staphylococcus }\end{array}$ & $\begin{array}{c}\text { Corynebacterium } \\
\text { (present in } 90 \% \text { of } \\
\text { all } \\
\text { samples) }\end{array}$ & - & - & - & $\begin{array}{c}\text { McEa- } \\
\text { chran } \\
\text { et al., } 2015\end{array}$ \\
\hline $\begin{array}{l}\text { Waste } \\
\text { Sorting } \\
\text { Plants }\end{array}$ & $\begin{array}{l}\text { Garbage type: } \\
\text { paper } \\
\text { Weight: } 4000 \\
\text { tons per month } \\
\text { (France) }\end{array}$ & $\begin{array}{l}\text { Biochemical } \\
\text { Identification }\end{array}$ & - & $\begin{array}{c}\text { unclassified } \\
\text { Enterobacteria- } \\
\text { ceae, Staphylo- } \\
\text { coccus, Acineto- } \\
\text { bacter }\end{array}$ & - & - & $\begin{array}{l}\text { Penicillium, } \\
\text { Aspergillus, } \\
\text { Rhizopus, } \\
\text { Wallemia }\end{array}$ & - & $\begin{array}{c}\text { Degois } \\
\text { et al., } 2017\end{array}$ \\
\hline \multirow[t]{2}{*}{$\begin{array}{l}\text { Landfill } \\
\text { Area }\end{array}$} & $\begin{array}{c}\text { Total area of } 37 \text { ha } \\
\text { Since } 1974 \\
\text { (Poland) }\end{array}$ & $\begin{array}{l}\text { Cultivation } \\
\text { Microscopy }\end{array}$ & & & & $\begin{array}{c}112-16445 \\
\left(\mathrm{CFU} / \mathrm{m}^{3}\right)\end{array}$ & $\begin{array}{l}\text { Aspergillus, } \\
\text { Cladosporium, } \\
\text { Penicillium }\end{array}$ & - & $\begin{array}{c}\text { Fraczek } \\
\text { et al., } 2017\end{array}$ \\
\hline & $\begin{array}{l}\text { The largest open } \\
\text { dumpsite in the } \\
\text { Philippines } \\
\text { Since: } 2000\end{array}$ & $\begin{array}{l}\text { Cultivation } \\
\text { Microscopy } \\
\text { and } \\
\text { Biochemical } \\
\text { Identification }\end{array}$ & $\begin{array}{c}7.87 \times 10^{2}- \\
5.57 \times 10^{3} \\
\left(\mathrm{CFU} / \mathrm{m}^{3}\right)\end{array}$ & $\begin{array}{c}\text { Staphylococcus, } \\
\text { Bacillus, } \\
\text { Enterococcus, } \\
\text { Pseudomonas, } \\
\text { Acinetobacter }\end{array}$ & $\begin{array}{l}\text { B. Subtilis, } \\
\text { S. Aureus, K. } \\
\text { Pneumoniae }\end{array}$ & - & - & - & $\begin{array}{c}\text { Pagali- } \\
\text { lauan } \\
\text { et al., } 2018\end{array}$ \\
\hline \multirow[t]{2}{*}{$\begin{array}{l}\text { Wastewater } \\
\text { Treatment } \\
\text { Plant }\end{array}$} & $\begin{array}{l}\text { Type: anaerobic-- } \\
\text { anoxic-oxic } \\
\left(\mathrm{A}^{2} / \mathrm{O}\right) \\
\text { Number: } 6.0 \times 10^{5} \\
\mathrm{~m}^{3} / \text { day } \\
\text { (China) }\end{array}$ & $\begin{array}{l}\text { Cultivation } \\
\text { Microscopy } \\
\text { and } \\
\text { Biochemical } \\
\text { Identification }\end{array}$ & $\begin{array}{l}459-4364 \\
\left(\mathrm{CFU} / \mathrm{m}^{3}\right)\end{array}$ & $\begin{array}{c}\text { Brevundimonas, } \\
\text { Bacillus, } \\
\text { Thauera, } \\
\text { Zooglea, } \\
\text { Dechloromonas }\end{array}$ & - & - & - & - & $\begin{array}{l}\text { Xu et al., } \\
2018\end{array}$ \\
\hline & $\begin{array}{c}\text { Type: activated } \\
\text { sludge } \\
\text { (Poland) }\end{array}$ & $\begin{array}{l}\text { Cultivation } \\
\text { Microscopy }\end{array}$ & $\begin{array}{c}5.1 \times 10^{1} \\
-6.9 \times 10^{3} \\
\left(\mathrm{CFU} / \mathrm{m}^{3}\right)\end{array}$ & $\begin{array}{l}\text { Staphylococcus, } \\
\text { Bacillus, } \\
\text { Pseudomonas, } \\
\text { Microbacterium }\end{array}$ & $\begin{array}{c}\text { Staphylococcus } \\
\text { gallinarum, } \\
\text { Staphylococcus } \\
\text { xylosus, } \\
\text { Bacillus firmus, } \\
\text { Pseudomonas } \\
\text { stutzeri }\end{array}$ & $\begin{array}{c}6.3 \times 10^{2} \\
-3.9 \times 10^{3} \\
\left(\mathrm{CFU} / \mathrm{m}^{3}\right)\end{array}$ & $\begin{array}{c}\text { Cladosporidies, } \\
\text { Rhodotorula, } \\
\text { Penicillium }\end{array}$ & $\begin{array}{c}\text { C.herbarum } \\
\text { Fusarium } \\
\text { graminearum }\end{array}$ & $\begin{array}{c}\text { Kowalski } \\
\text { et al., } 2017\end{array}$ \\
\hline
\end{tabular}


poultry operation and altered the microbial community of the plant leaves in the orchard. This study provides evidence for the spread of bioaerosols from farms. Meanwhile, many pathogenic bacteria can often be detected in the air near these farms. The main pathogenic bacteria in the atmosphere of farms include Bacillus, Corynebacterium, and Streptococcus (McEachran et al., 2015; Skora et al., 2016; Dai et al., 2020), which are mainly derived from animal excrement and feed or are related to the farming activities in the farm (Zhang et al., 2019).

The WWTP is another well-studied source of bioaerosols. Each treatment process of WWTPs was found to have variable effects on the release of bioaerosols (Michalkiewicz, 2019). The reported concentration of culturable fungus aerosol was $6.3 \times 10^{2}-3.9 \times 10^{3} \mathrm{CFU} / \mathrm{m}^{3}$, and that of culturable bacteria aerosol was $5.1 \times 10^{1}-$ $6.9 \times 10^{3} \mathrm{CFU} / \mathrm{m}^{3}$ in the WWTPs (Kowalski et al., 2017; $\mathrm{Xu}$ et al., 2018). Many microorganisms, toxins, and metabolites are released from most of the treatment units into the air to form bioaerosols (Hsiao et al., 2020). These bioaerosols concentrated in the air and were carried by the wind to the neighboring regions. At the receptor site, the transported bioaerosols became a source of pollution for plants, animals, and surface water, and affected people inhabiting in places both near and far from WWTPs (Sialve et al., 2015; Michalkiewicz, 2019). Compared with WWTPs, the landfill sites had relatively higher concentrations of microorganisms and were richer in pathogenic bacteria (b. Subtilis, s. Aureus, $k$. neumoniae) (Pagalilauan et al., 2018; Xu et al., 2018). As landfill sites generally are an open space, their impact on the surrounding environment is far more significant than that of other workplaces.

It is evident that the concentration and composition of bioaerosols in artificial sources are different due to different release processes (Xu et al., 2018). The knowledge of bioaerosol emission characteristics in various workplaces will enhance the understanding of pollution sources. Further, this will aid in estimating pollution levels, formulating mitigation measures, and improving air quality. Therefore, more emission and distribution studies on bioaerosols around the multifarious workplaces should be given additional focus in the field of airborne microorganisms.

\section{Diffusion and transport}

After their release into the atmosphere, most bioaerosols combine with the ambient particulate matter for diffusion and transport. Bioaerosols can be dispersed or transported over long distances, and thus may become another source of bioaerosols.

\subsection{Diffusion and transport process}

As also shown in Fig. 2, the diffusion and transport mechanisms of bioaerosols are extraordinarily complex. Microorganisms enter the atmosphere as aerosols from the sources mentioned above. Once in the air, microbes are carried upward by the airflow owing to their small size, where they attach onto existing particles. Therefore, particle size has a significant impact on the transport of bioaerosols. The presence of bioaerosols in the air for long durations provides favorable conditions for their transport. Under the action of wind, bioaerosols may travel from a source to a receptor site. Ultimately, bioaerosols are scavenged from the atmosphere either by precipitation or by direct deposition to the surface. However, some human activities may prevent the settling of bioaerosols, causing the microbes to re-levitate.

Long-distance transport is an important mode of the dispersal of bioaerosols that affects the ecosystem, human health, agricultural productivity, and climate change (Burrows et al., 2009b; Rodo et al., 2011; FröhlichNowoisky et al., 2016; Murata and Zhang, 2016; Uetake et al., 2019; Mu et al., 2020). The bioaerosols released from the earth's surface are under the constant influence of pressure and temperature. Only a small fraction of bioaerosols will mix with the air in the troposphere with the help of wind. For example, Firmicutes are present in large quantities on the surface of the Gobi Desert, and they are mostly eliminated because of pressure and thereby constitute only $5 \%$ in the air sample as a mixture of bioaerosols that undergo atmospheric transport with air masses (Tang et al., 2018).

During the atmospheric transport process, bioaerosols may interact with ultraviolet (UV) radiation, photooxidants, and various air pollutants. These interactions may lead to further chemical and physical transformations and biological aging of bioaerosols during transport. When bioaerosols are exposed to atmospheric oxidants (such as $\mathrm{OH}, \mathrm{NO}_{3}$, and $\mathrm{O}_{3}$ ) in the air, they rapidly change from their original emission state (Estillore et al., 2016). These oxidants could significantly alter the composition and properties of bioaerosols by homogeneous and heterogeneous chemical reactions. For example, a direct attack by reactive oxygen species could damage the biological systems (Anglada et al., 2015). However, aggregation of cells or protective envelopes may influence the viability of bioaerosols (Amato et al., 2015; Fröhlich-Nowoisky et al., 2016). Some highly stress-resistant microorganisms found in the deserts can thrive in severe environmental conditions (lack of water, extreme temperatures, and UV radiation) (Varin et al., 2012; Makhalanyane et al., 2015).

Extreme weather conditions such as rain, snow, or dust storms, scavenge the microorganisms from the atmosphere and return them to the ground to influence the local microbial community structure. The dust-laden weather is also recognized as one of the dry sedimentation methods in the long-distance transport process. For example, with the spread of East Asian dust, the airborne microbial communities in China, Japan, Republic of Korea, and 
other places have been seriously affected, increasing the prevalence rate of some respiratory diseases (Tang, 2009; Rodo et al., 2011; Cha et al., 2016; Maki et al., 2018; Tang et al., 2018). In addition, Saharan dust also had a significant impact on airborne microbial communities and human health in Europe and America (Garrison et al., 2014; Barnaba et al., 2017; Oduber et al., 2019). Hence, exploring the transport process and transport route of airborne microorganisms can help to gain a more indepth insight into the biogeochemical cycles of bioaerosols and improve the understanding of air pollution and public health induced from bioaerosols.

\subsection{Diffusion and transport models}

In order to control haze pollution and health risks associated with bioaerosols, it is necessary to understand the physical and biological dynamics inherent in the microorganisms transmitted by aerosols. Because it is challenging and expensive to test the diffusion and transport process of airborne microorganisms, a diffusion and transport model has become a promising alternative. At present, three kinds of models are commonly used: mathematical models, physical models that use nonbiological simulation, and physical models that use biological simulations. Each of the three simulation methods has its advantages and disadvantages (Table 2).

Among the three models, mathematical models are used most widely in the present (Sesartic et al., 2012; Burrows et al., 2013; Ansari et al., 2015; Hummel et al., 2015). Such models allow the generation of relevant data without the risk of being associated with a living biological organism and are relatively simple to operate. Since they are freely used in simulations to simplify calculations, mathematical models raise critical questions about their accuracy and realism. In order to determine the accuracy of a given model, it should be directly compared with empirical results gathered from a similarly constructed physical simulation. Therefore, the establishment of a physical model plays a vital role in the validation of mathematical models. However, it must be noted that physical models (such as the gas dispersion model and particulate model) are more suitable for the simulation of general aerosols (Chao et al., 2014). Microorganisms are the best indicator to track the movement of bioaerosols. The advantage of using microbial indicator is that the uncertainty of whether the indicator correctly simulates a particular scene can be significantly reduced, even almost completely, and the use of bacterial growth as a detection parameter is allowed (Wong et al., 2010; Garza et al., 2014). However, the potential pathogenic issues that may arise in the process of biological simulation should not be ignored.

Below we summarize some of the commonly used models:

The computational fluid dynamics (CFD) model is a complex computational model that simulates the diffusion trajectory of fluids in different environments. It is widely used to simulate the diffusion of bioaerosols in local regions, especially in indoor environments. For example, Lee et al. (2013) simulated the diffusion trajectories of various phenomena in the agricultural environment, such as gaseous pollutant emissions from livestock farms and particulate emissions from farmlands. Similarly, Thatiparti et al. (2017) and Lin et al. (2018) used the CFD model to simulate the spread of the virus and provide a basis for disease prevention and control. The use of this model can significantly reduce the cost of fieldwork. At the same time, different environmental conditions can be adjusted easily to obtain the diffusion mode of bioaerosols under variable environmental conditions.

The Hybrid Single Particle Lagrange Integrated Trajectory model (HYSPLIT) is one of the most frequently used mathematical models in atmospheric science to investigate long-distance transport (Stein et al., 2015). HYSPLIT provides possible long-distance transport routes of the air mass, which is valuable for determining the potential origin of microorganisms. For instance, Cáliz et al. (2018) used HYSPLIT to analyze the airflow tracks and identify possible source regions of microbial communities transported to the receptor sites with air masses. Their study

Table 2 Advantages and limitations of different types of diffusion and transport models

\begin{tabular}{|c|c|c|c|}
\hline Model Type & Characteristic & Advantage & Limitation \\
\hline Mathematical Model & $\begin{array}{l}\text { Mathematics and computer model; } \\
\text { Simulate under specific parameters }\end{array}$ & $\begin{array}{c}\text { Avoid building complex structures; } \\
\text { Detect different scenarios by changing } \\
\text { variables; } \\
\text { No environmental pollution problem; } \\
\text { Reduce time and expenses }\end{array}$ & $\begin{array}{l}\text { Need to integrate data across the } \\
\text { environment; } \\
\text { Test in the ideal environment }\end{array}$ \\
\hline Non-biological Simulant Model & $\begin{array}{l}\text { Create an artificial environment } \\
\text { similar to the simulated scene }\end{array}$ & $\begin{array}{c}\text { Have authenticity; } \\
\text { Experimental particles are less harmful to } \\
\text { human body }\end{array}$ & $\begin{array}{c}\text { Cause environmental pollution; } \\
\text { Spend a lot of money; } \\
\text { Be differences between test particles and } \\
\text { biological particles }\end{array}$ \\
\hline Biological Simulant Model & Use a biological simulant & $\begin{array}{l}\text { Experimental particles are more realistic; } \\
\text { Significantly reduce model uncertainty }\end{array}$ & $\begin{array}{l}\text { Cause environmental pollution or the } \\
\text { spread of pathogenic bacteria; } \\
\text { Spend a lot of money; } \\
\text { Need to design experimental apparatus }\end{array}$ \\
\hline
\end{tabular}


provides reliable information for determining the longdistance migration rule of microorganisms. Besides, it was reported that the composition and size distribution of bacterial communities in marine bioaerosols might be affected by the long-distance transport of bioaerosols from land (Ma et al., 2019).

The models mentioned above do not consider the activity changes and atmospheric chemical reactions of microorganisms during the transport process. To overcome this limitation, global and regional models have been proposed to simulate aerosol spread, transportation, and their effects in the atmosphere (Burrows et al., 2009a; Burrows et al., 2009b; Hoose et al., 2010; Burrows et al., 2013; Ansari et al., 2015). Burrows et al. (2009a) simulated bacterial exchange between different ecosystems and their migration in the global atmosphere using the Global Chemical-Climate model (EMAC). Using their simulations, they obtained the typical concentration and flux distribution of atmospheric bacteria. Currently, General Circulation Model (GCM) and its evolution model (ECHAM5, the rope-climate model CAM-Oslo) are commonly used (Hoose et al., 2010; Sesartic et al., 2012) to explore the regional diffusion of bioaerosols. These models can improve prediction accuracy by considering the emission and biochemical properties of the particles and their possible changes in the atmosphere. However, more accurate determination of these properties and changes in the atmosphere are still required.

\section{Factors affecting the diffusion and trans- port of bioaerosols}

\subsection{Geographical location}

As discussed earlier, soil and plants are one of the primary natural sources of bioaerosols. The structure and species diversity of microorganisms in soil and plant have distinct geographical differences, so-called biogeography, and are greatly influenced by a wide range of climatic and geomorphic conditions (Chi et al., 2014; Wang et al., 2019). Therefore, significant variations in the composition of airborne microbial communities can be expected at different geographical locations. Geographical location is one of the main factors affecting the composition of airborne microorganisms.

Table 3 compares the microbial community structures in air samples from different regions around the world. Most regions of China fall in the subtropical and temperate zone, with a vast territory and complex landforms. The main climate types are continental climate and monsoon climate. The dominant bacteria in Changsha (Runlan et al., 2019) and Urumqi (Gou et al., 2016) were found to be Proteobacteria $(81.2 \%, 74.10 \%)$. On the other hand, the more abundant bacteria observed in Beijing were Actinobacteria (28.12\%) and Firmicutes (19.30\%) (Du et al.,
2018). Furthermore, apparent differences at the genus level are also observed in different geographical regions. For example, the dominant bacteria were Serratia and Delftia in Urumqi (Gou et al., 2016), Comamonadaceae and Bacillus in Changsha (Runlan et al., 2019), Pseudomonas in Xi'an (Lu et al., 2018), Lactococcus in Jinan (Xu et al., 2017), and Arthrobacter in Beijing (Li et al., 2018). Although the dominant Ascomycota and Basidiomycota account for more than $95 \%$ of the relative abundance of fungi, regional variations in relative abundance are observed (Changsha, 44.6\%, 54.9\%; Beijing, 95.37\%, $1.51 \%$ ) (Du et al., 2018; Runlan et al., 2019).

Denver is located in the western USA and belongs to a highland climate. The dominant bacteria phylum in Denver is Proteobacteria (34.6\%) and Firmicutes (28.2\%), while the dominant phylum of fungi is Ascomycota (78\%) and Basidiomycota (21\%) (Bowers et al., 2013). Thessaloniki and Madrid belong to the Mediterranean climate type. Proteobacteria, Actinobacteria, and Firmicutes are the dominant phylum in the two cities, but there are large variations in the predominant bacteria phylum (Genitsaris et al., 2017; Núñez et al., 2019). The bacteria and fungi communities detected at the two mountainous sites of Mount Tai and Mount Fuji are also quite different (Tanaka et al., 2019; Xu et al., 2019), which might be related to differences in mountain climates and vegetation types. In addition, the main bacterial phylum above the sea surface (the western Pacific Ocean) was Bacteroidetes, which was significantly different from the inland bacterial communities (Ma et al., 2019).

The community composition of airborne microorganisms varies significantly in different geographical regions. This is due to the significant differences in species diversity of the microbial communities in different habitat types (Nemergut et al., 2011; Xiong et al., 2012), which further affects the discharge of bioaerosols. This means that the biogeographical differences significantly affect the concentration and composition of bioaerosols, which are directly related to microbial emission sources and diffusion conditions.

\subsection{Different types of land-use}

Land-use is a kind of intervention to the circumstance, for meeting the needs of human production and life. Land-use may create a "microenvironment" with specific environmental attributes, which may play a critical role in the generation, propagation, aerosolization, re-suspension, diffusion, transport, and intermolecular interactions of bioaerosols (Balyan et al., 2017).

At present, there is no unified standard for the classification of land-use types. We introduce the four categories of urban, suburban, agriculture, and forest in this review. In general, there are significant differences in the total microbial abundance, total ice core number, and bacterial communities in the suburbs, farming, and 
Table 3 The airborne microbial communities in different regions worldwide

\begin{tabular}{|c|c|c|c|c|c|c|c|c|}
\hline \multirow{2}{*}{ Region } & \multirow{2}{*}{$\begin{array}{l}\text { Geographical } \\
\text { conditions }\end{array}$} & \multirow{2}{*}{ Climate type } & \multirow{2}{*}{ Sampling } & \multicolumn{2}{|c|}{ Bacteria } & \multicolumn{2}{|c|}{ Fungi } & \multirow{2}{*}{ Reference } \\
\hline & & & & Phyla & Dominant genera & Phyla & Dominant genera & \\
\hline $\begin{array}{l}\text { Urumqi, } \\
\text { China }\end{array}$ & $\begin{array}{l}\text { An important } \\
\text { central city in } \\
\text { north-west } \\
\text { China }\end{array}$ & $\begin{array}{l}\text { Temperate conti- } \\
\text { nental climate }\end{array}$ & $\mathrm{PM}_{10}$ & $\begin{array}{c}\text { Proteobacteria } \\
(74.1) \\
\text { Firmicutes }(15.3) \\
\text { Actinobacteria }(6.2)\end{array}$ & $\begin{array}{c}\text { Pseudomonas } \\
\text { Delftia } \\
\text { Serratia } \\
\text { Acinetobacter }\end{array}$ & - & - & $\begin{array}{l}\text { Gou et al., } \\
2016\end{array}$ \\
\hline $\begin{array}{l}\text { Changsha, } \\
\text { China }\end{array}$ & $\begin{array}{l}\text { A city in the } \\
\text { middle reaches } \\
\text { of the Yangtze } \\
\text { river in China }\end{array}$ & $\begin{array}{l}\text { Subtropical } \\
\text { monsoon climate }\end{array}$ & $\mathrm{PM}_{2.5}$ & $\begin{array}{l}\text { Proteobacteria } \\
\quad(95.6) \\
\text { Firmicutes (3.4) }\end{array}$ & $\begin{array}{c}\text { Acinetobacter } \\
\text { Massillia } \\
\text { Xanthomonadaceae }\end{array}$ & $\begin{array}{c}\text { Ascomycota (44.6) } \\
\text { Basidiomycota } \\
(54.9)\end{array}$ & $\begin{array}{c}\text { Polyporales } \\
\text { Aspergillus } \\
\text { Schizophyllum }\end{array}$ & $\begin{array}{l}\text { Runlan } \\
\text { et al., } 2019\end{array}$ \\
\hline $\begin{array}{l}\text { Mount Tai, } \\
\text { China }\end{array}$ & $\begin{array}{l}\text { The highest } \\
\text { mountain in the } \\
\text { North China } \\
\text { Plain }\end{array}$ & $\begin{array}{l}\text { Monsoon climate } \\
\text { of medium lati- } \\
\text { tudes (Significant } \\
\text { vertical variation) }\end{array}$ & $\mathrm{PM}_{2.5}$ & $\begin{array}{c}\text { Proteobacteria } \\
(60.6) \\
\text { Firmicutes }(3.0) \\
\text { Actinobacteria } \\
(15.3) \\
\text { Cyanobacteria }(9.8)\end{array}$ & $\begin{array}{l}\text { Methylobacterium } \\
\text { Rhodococcus } \\
\text { Pseudomonas } \\
\text { Acinetobacter }\end{array}$ & $\begin{array}{l}\text { Ascomycota (84.2) } \\
\text { Basidiomycota (3.8) }\end{array}$ & $\begin{array}{c}\text { Alternaria } \\
\text { Davidiella } \\
\text { Epicoccum } \\
\text { Cryptococcus }\end{array}$ & $\begin{array}{l}\text { Xu et al., } \\
2019\end{array}$ \\
\hline Beijing, China & $\begin{array}{l}\text { The capital of } \\
\text { China, located } \\
\text { in the north of } \\
\text { the North } \\
\text { China Plain }\end{array}$ & $\begin{array}{l}\text { Monsoon climate } \\
\text { of medium } \\
\text { latitudes }\end{array}$ & $\mathrm{PM}_{2.5}$ & $\begin{array}{l}\text { Proteobacteria (33) } \\
\text { Actinobacteria } \\
\quad(28.1) \\
\text { Firmicutes }(19.30) \\
\text { Bacteroidetes }(8.14)\end{array}$ & $\begin{array}{c}\text { Streptophyta, } \\
\text { Kocuria, } \\
\text { Paracoccus, } \\
\text { Sphingomonas, } \\
\text { Rubellimicrobium }\end{array}$ & $\begin{array}{c}\text { Ascomycota }(95.37) \\
\text { Basidiomycota } \\
(1.51) \\
\text { Zygomycota }(0.13)\end{array}$ & $\begin{array}{c}\text { Epicoccum } \\
\text { Penicillium } \\
\text { Selenophoma } \\
\text { Mycosphaerella } \\
\text { Cladosporium }\end{array}$ & $\begin{array}{l}\text { Du et al., } \\
2018\end{array}$ \\
\hline Denver, USA & $\begin{array}{l}\text { The largest } \\
\text { urban city in } \\
\text { the Colorado } \\
\text { Front Range }\end{array}$ & Highland climate & $\mathrm{PM}_{10} \& \mathrm{PM}_{2.5}$ & $\begin{array}{c}\text { Actinobacteria (22) } \\
\text { Bacteroidetes (9.7) } \\
\text { Firmicutes (28.2) } \\
\text { Proteobacteria } \\
\text { (34.6) }\end{array}$ & - & $\begin{array}{l}\text { Ascomycota (78) } \\
\text { Basidiomycota }(21)\end{array}$ & - & $\begin{array}{l}\text { Bowers } \\
\text { et al., } 2013\end{array}$ \\
\hline $\begin{array}{c}\text { Thessaloniki, } \\
\text { Greece }\end{array}$ & $\begin{array}{c}\text { The largest port } \\
\text { and second city } \\
\text { in northern } \\
\text { Greece }\end{array}$ & $\begin{array}{l}\text { Mediterranean } \\
\text { climate }\end{array}$ & Bioaerosol & $\begin{array}{l}\text { Proteobacteria } \\
\qquad(56.0) \\
\text { Firmicutes }(20.0) \\
\text { Actinobacteria } \\
\quad(20.0)\end{array}$ & $\begin{array}{l}\text { Pseudomonas } \\
\text { Herbaspirillum } \\
\text { Bacillus }\end{array}$ & & & $\begin{array}{l}\text { Genitsaris } \\
\text { et al., } 2017\end{array}$ \\
\hline $\begin{array}{l}\text { Madrid, } \\
\text { Spain }\end{array}$ & $\begin{array}{l}\text { The capital and } \\
\text { largest metro- } r \\
\text { polis of Spain }\end{array}$ & $\begin{array}{l}\text { Temperate conti- } \\
\text { nental climate with } \\
\text { Mediterranean } \\
\text { climate character- } \\
\text { istics }\end{array}$ & Bioaerosol & $\begin{array}{l}\text { Proteobacteria } \\
\text { Firmicutes } \\
\text { Actinobacteria }\end{array}$ & $\begin{array}{c}\text { Kocuria } \\
\text { Arthrobacter } \\
\text { Sphingomonas } \\
\text { Pantoea }\end{array}$ & $\begin{array}{c}\text { Ascomycota } \\
\text { Basidiomycota } \\
\text { Chytridiomycota }\end{array}$ & $\begin{array}{c}\text { Davidiella } \\
\text { Cladosporium } \\
\text { Alternaria } \\
\text { Aureobasidlum }\end{array}$ & $\begin{array}{l}\text { Núñez } \\
\text { et al., } 2019\end{array}$ \\
\hline $\begin{array}{c}\text { Gwangju } \\
\text { Metropolitan } \\
\text { City, Republic } \\
\text { of Korea }\end{array}$ & $\begin{array}{l}\text { Located in the } \\
\text { south-west of } \\
\text { c Republic of } \\
\text { Korea }\end{array}$ & $\begin{array}{l}\text { West coast type } \\
\text { climate }\end{array}$ & $\mathrm{PM}_{2.5}$ & - & - & $\begin{array}{l}\text { Ascomycota } \\
\text { Basidiomycota }\end{array}$ & $\begin{array}{c}\text { Phaeosphaeria } \\
\text { Pyrenophora } \\
\text { Botryotinia }\end{array}$ & $\begin{array}{l}\text { Abd Aziz } \\
\text { et al., } 2018\end{array}$ \\
\hline $\begin{array}{l}\text { The North- } \\
\text { western Paci- } \\
\text { fic Ocean, } \\
\text { China }\end{array}$ & $\begin{array}{l}\text { The Bohai Sea; } \\
\text { The Yellow } \\
\text { Sea; The north- } \\
\text { western Pacific } \\
\text { Ocean } \\
\text { (a ship cruise) }\end{array}$ & $\begin{array}{l}\text { Monsoon climate } \\
\text { of medium } \\
\text { latitudes }\end{array}$ & Bioaerosol & $\begin{array}{c}\text { Bacteroidetes } \\
(26.99) \\
\text { Firmicutes }(26.72) \\
\text { Proteobacteria } \\
(21.8)\end{array}$ & $\begin{array}{c}\text { Bacteroides }(9.56) \\
\text { Prevotella }(5.42) \\
\text { Megamonas }(3.22)\end{array}$ & & & $\begin{array}{l}\text { Ma et al., } \\
2019\end{array}$ \\
\hline $\begin{array}{l}\text { Toyama Pre- } \\
\text { fecture, Japan }\end{array}$ & $\begin{array}{l}\text { Surrounded by } \\
\text { steep } \\
\text { mountains on } \\
\text { three sides and } \\
\text { spreading fields }\end{array}$ & $\begin{array}{l}\text { Oceanic climate } \\
\text { (snow coverage } \\
\text { throughout the } \\
\text { year in top) }\end{array}$ & Bioaerosol & $\begin{array}{c}\text { Proteobacteria } \\
(49.1) \\
\text { Actinobacteria } \\
(26.3) \\
\text { Firmicutes }(14.0)\end{array}$ & - & $\begin{array}{c}\text { Basidiomycota } \\
\text { (41.7) } \\
\text { Ascomycota (30.9) } \\
\text { Streptophyta (14.9) }\end{array}$ & $\begin{array}{c}\text { Alternaria } \\
\text { Epicoccum } \\
\text { Curvularia } \\
\text { Cladosporium }\end{array}$ & $\begin{array}{c}\text { Tanaka } \\
\text { et al., } 2019\end{array}$ \\
\hline
\end{tabular}

forested environments (Bowers et al., 2011a) (Fig. 4). The microbial concentration and communities in the suburbs were markedly different from the mountainous areas due to frequent human activities in the former (Mu et al., 2020; Qi et al., 2020). Urban land can be further divided into urban green spaces, residential areas, and commercial areas.
Balyan et al. (2020) found significant differences in the concentrations of fungal and bacterial bioaerosols in urban land with different usages (green space, residential area, and commercial area). The concentration of bacterial aerosols was higher in commercial areas. In comparison, the concentration of fungal aerosols was more elevated in 

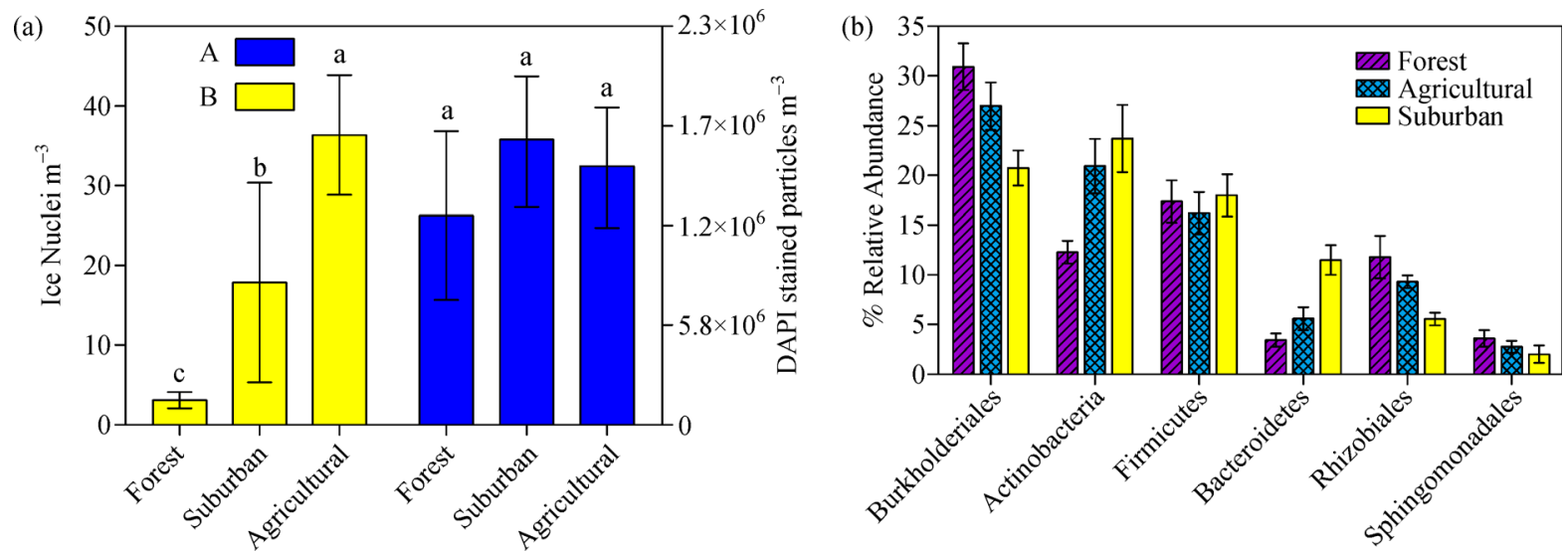

Fig. 4 Bioaerosol characteristics of different land-use types. (a) "A" Bacterial abundance of varying land-use types, "B" the total number of ice nuclei. (b) The dominant bacterial phyla in samples of different land-use types. Adapted from Bowers et al. (2011a).

green spaces. Besides, the urban green space area also influenced the bacterial community in the air (Mhuireach et al., 2016).

The differences in agricultural land is mainly due to farming methods and the main crops cultivated. A study showed that the effects of fungi released during the harvest process were related to the types of grain and cultivated land (Pellissier et al., 2016). The effects of fertilization on airborne microorganisms could not be ignored (Jahne et al., 2016). Factories, WWTPs, landfill plants, farms, and other human activities areas are mostly located in the suburban regions. As indicated earlier, different activities will produce different bioaerosols. These bioaerosols could also have an impact on the surrounding environment (Michalkiewicz, 2019). Forested areas are less affected by human activities and have their own unique ecosystems. Different plant types have different microbial communities on the leaf surface, making the forest have a very unusual microbial community (Redford et al., 2010). The adhesion and maintenance of leaves to air particles reduce the resuspension of particles (Nguyen et al., 2015).

Since airborne microorganisms change with the source, and specific microbial communities have been found on different soil and leaf surfaces, it can be expected that landuse types will also have a vital influence on airborne microbial communities (Després et al., 2007; Bowers et al., 2011a; Balyan et al., 2020; Qi et al., 2020). Further studies should investigate the characteristics of airborne microorganisms in varying land-use types. This analysis will be conducive to rational planning of land-use patterns and control of the impact of bioaerosol emissions on human beings.

\subsection{Environmental factors}

As mentioned above, the structure of the bioaerosol community varies regionally. However, even at the same site, the microbial community structure has been found to have a distinct seasonal distribution pattern. This indicates that the structure of the microbial community is also linked to environmental conditions (meteorological factors and air pollution).

\subsubsection{Meteorological factors}

Jones and Harrison (2004) wrote an insightful overview of the influences of meteorological factors on bioaerosol concentrations. Their results indicated that temperature and relative humidity affected the amount of emission from the source and controlled the release process of actively released fungal spores. Further, compared with soil surface microorganisms, microorganisms on the surface of plants were affected more at lower wind speeds and re-suspended in the air. In addition, solar UV radiation can potentially sterilize the ambient air from bioaerosols, a phenomenon more effective for airborne bacteria (Kowalski and Pastuszka, 2018).

Rainfall could also affect the concentration of microorganisms in the air. On the one hand, some studies showed that raindrops released a large number of bioaerosol particles from the plant and soil surface into the atmosphere, increasing the concentration of microorganisms. On the other hand, some studies have also shown that raindrops transported bioaerosols from high altitudes to the surface environment (Kang et al., 2015).

We used correlation analysis based on high-throughput sequencing data to study the extent to which various meteorological factors affect different species and genera of bacteria. Spearman's rank correlation was used to examine the correlation between airborne bacteria with relatively high abundance and meteorological factors. The results show that bacteria of different genera had different responses to various meteorological factors (Fig. 5). The atmospheric levels of most bacteria were positively correlated with temperature, relative humidity, and wind speed. However, some bacteria, such as Thermus, Bacillus, 


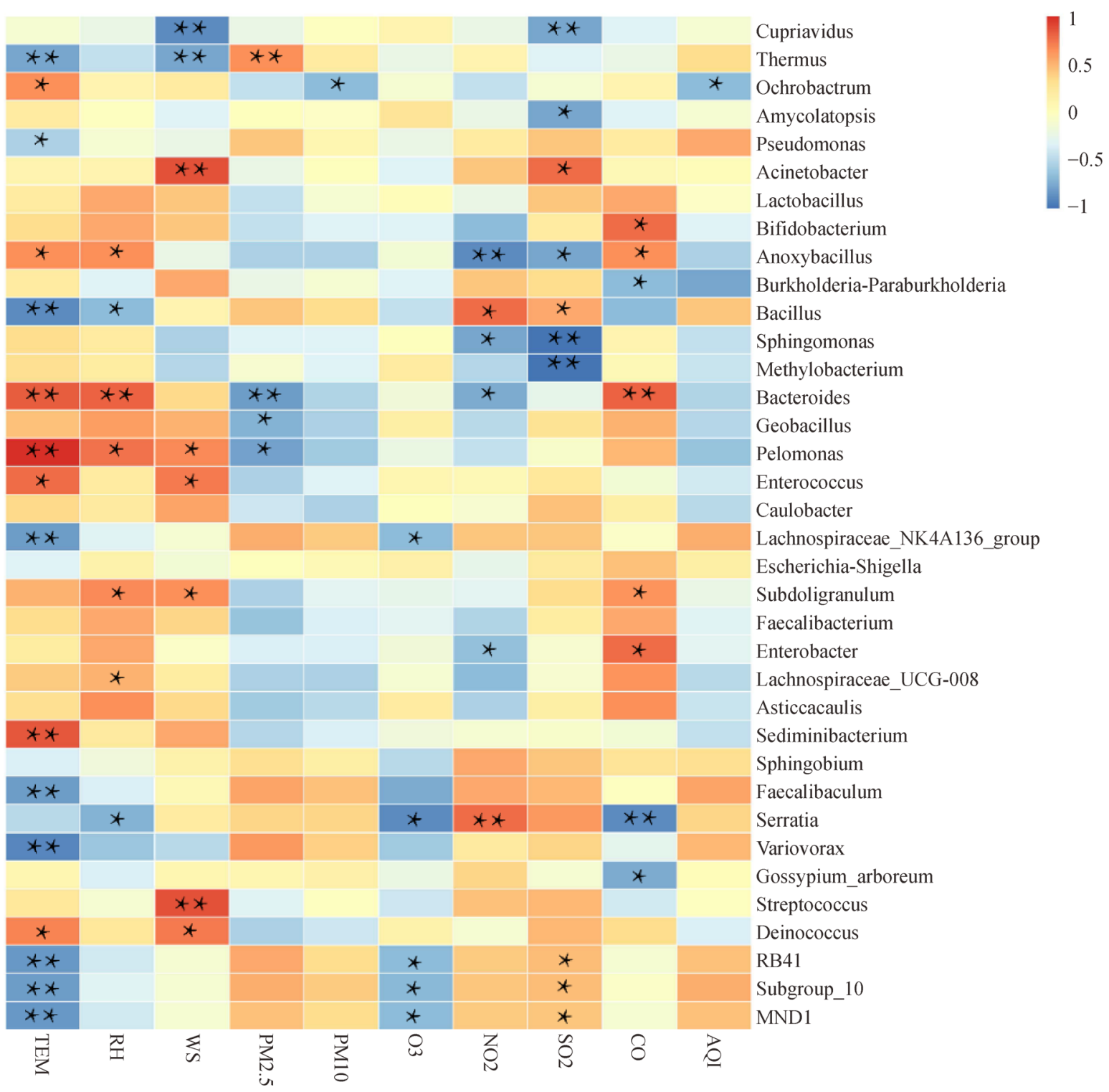

Fig. 5 Analysis of heatmap of dominant bacteria genera in Xi'an, China, based on Spearman rank correlation $\left(* * p<0.01 ; *^{*} p<0.05\right)$.

and Variovorax, were negatively correlated with ambient temperature. Therefore, correlation analysis may provide a possibility for further exploring the relationships between bioaerosols and meteorological factors from the point of view of specific components.

\subsubsection{Air pollution}

Zhen et al. (2017) and Xie et al. (2018) presented two overviews of the effects of air pollutions on atmospheric bioaerosols, respectively. Xie et al. (2018) concluded that the concentration of bioaerosols was higher during the haze, but tended to decline under conditions with high pollutant loading. Toxic substances and heavy metals on the particulate matter also increase with the increase in pollutant concentration, proving harmful to the micro- organisms. In addition, they concluded that the effects of gaseous air pollutants $\left(\mathrm{SO}_{2}, \mathrm{CO}\right)$ on bioaerosols were controversial and needed further exploration. Zhen et al. (2017) found that the impact of air pollutants on bioaerosols was smaller than the meteorological factors. This might have been the result of the apparent seasonality of gas-phase and particle-phase pollutant emissions. Besides, the pollutant loading was constrained by meteorological factors.

In addition, most studies on the effects of pollutants on bioaerosols focused on qualitative correlation analysis. However, little is known about the quantitative impact of different types of pollutants on bioaerosols. Recently, two quantitative methods were used to determine the relationship between environmental factors and bioaerosols: aggregated boosted trees (ABT) (Fan et al., 2019) and 
multivariate regression trees (MRT) (Qi et al., 2020). Fan et al. (2019) indicated that atmospheric pollutants had varying levels of effects on the potential airborne pathogenic bacteria (Fig. 6(a)). Among them, the mass concentration of $\mathrm{PM}_{10}$ and $\mathrm{PM}_{2.5}$ were the dominant factors that affected the potential pathogenic bacteria in $\mathrm{PM}$, accounting for $27.56 \%$ and $19.88 \%$ of the relative influence, respectively. In addition, $\mathrm{SO}_{2}$ and $\mathrm{NO}_{2}$ also had different effects on pathogenic bacteria community composition in $\mathrm{PM}_{10}(6.70 \%, 6.79 \%)$ and $\mathrm{PM}_{2.5}$ $(11.36 \%, 11.92 \%)$. As for fungal bioaerosol, Qi et al. (2020) showed that the abundance of airborne fungal community was significantly affected by the level of particulate pollution $(42.8 \%)$, followed by $\mathrm{O}_{3}(22.57 \%)$ (Fig. 6(b)).

The above sections summarize the effects of geographical location, land use types, and environmental conditions on bioaerosols. It can be seen that the factors affecting bioaerosols are very complex. At present, we have not been able to reach a unified conclusion on the transport and diffusion of bioaerosols. Hence, further research studies should use advanced statistical methods such as independent variable screening, collinear diagnosis, principal component analysis to re-integrate the potential influencing factors and better clarify the interactions between them.

\section{Source identification}

In order to accurately identify the origin of airborne microorganisms and reliably estimate the effects of bioaerosols on the atmosphere, it is essential to know the exact contribution rate of each source of microorganisms. Various source identification methods have been developed to accomplish this. At present, the identification of bioaerosol sources is mainly based on biochemical
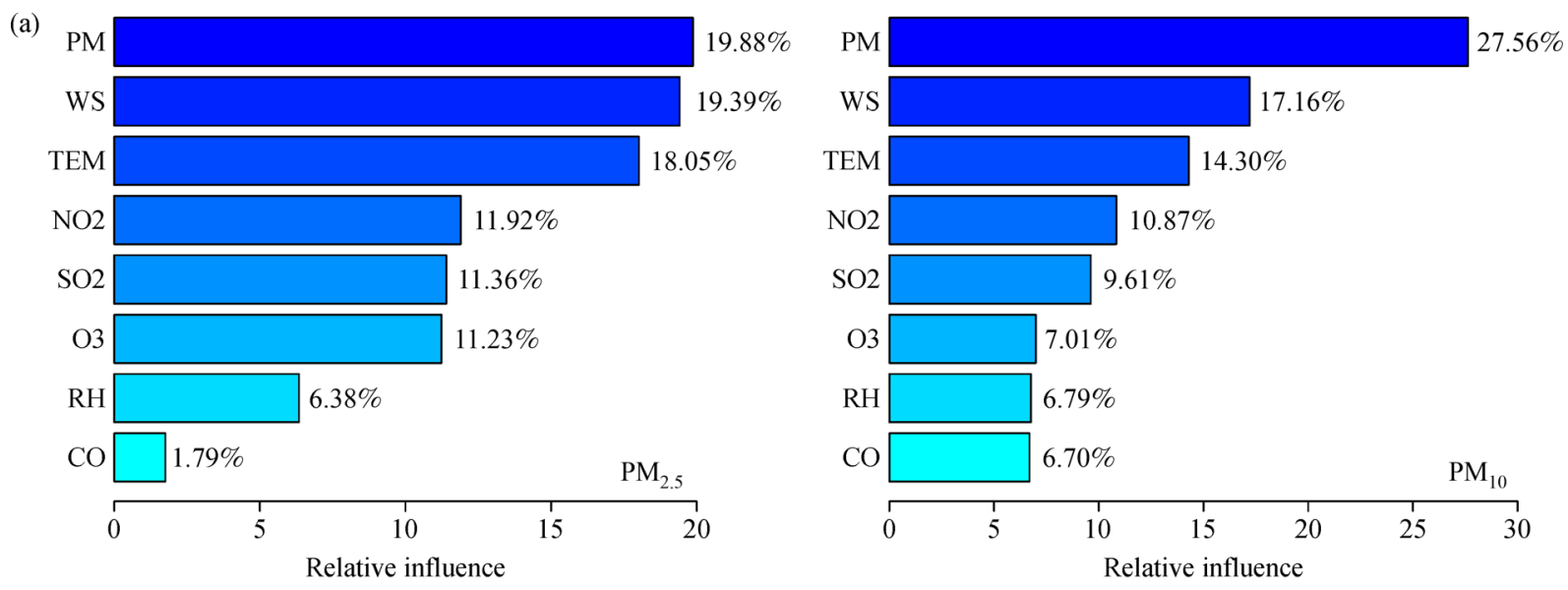

(b) $\quad \mathrm{PM}_{2.5} \geqslant 74.00 \mu \mathrm{g} / \mathrm{m}^{3} \mid \mathrm{PM}_{2.5}<74.00 \mu \mathrm{g} / \mathrm{m}^{3}$

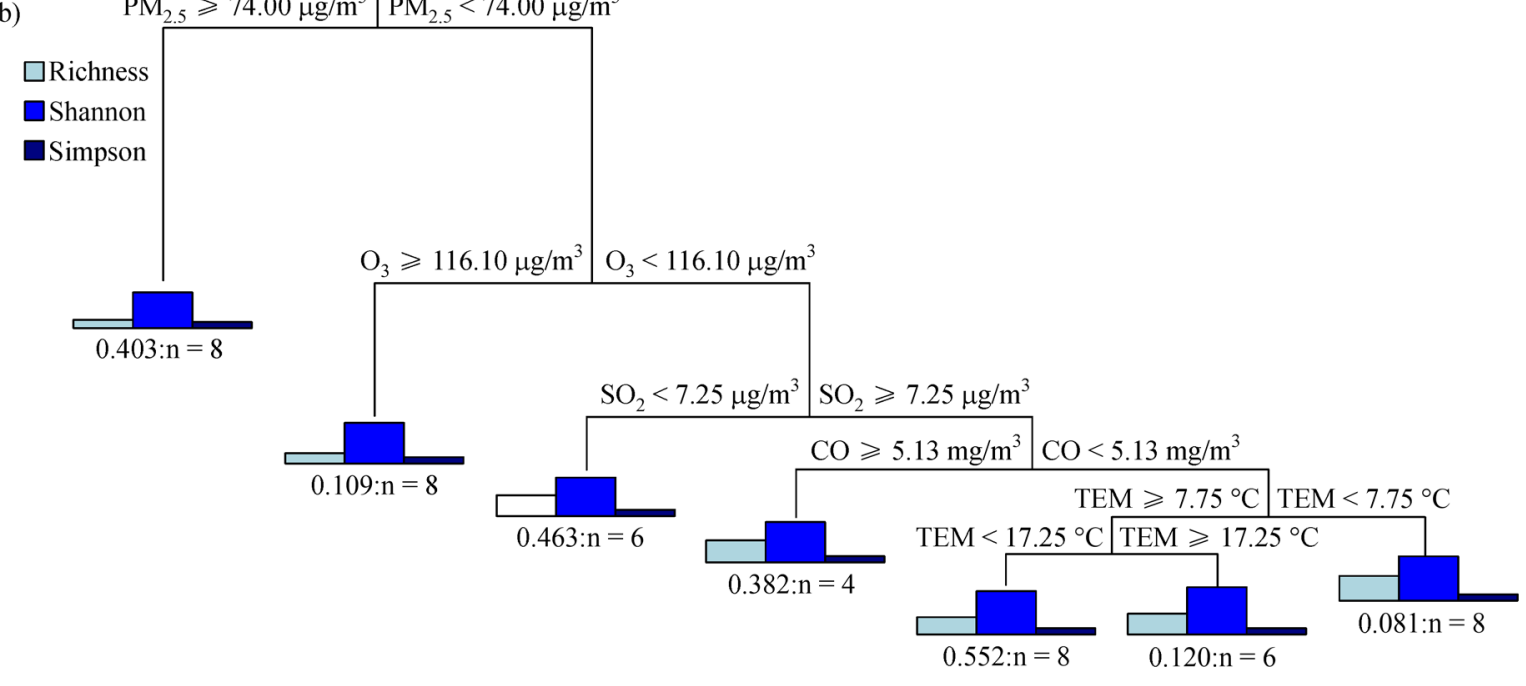

Error: 0.0642 CV Error: 0.14 SE: 0.0261

Fig. 6 Effects of environmental factors on bioaerosols. (a) Relative effects of environmental conditions on opportunistic pathogens in particulate matter (Reprint from Fan et al. (2019) with permission of Elsevier); (b) Effect of environmental conditions on the richness and diversity of airborne fungus (Reprint from Qi et al. (2020) with permission of Elsevier). 
techniques.

\subsection{Source identification methods}

There are three ways to identify the sources of microorganisms in aerosols, namely database analysis method (DAM), correlation analysis method (CAM), and model analysis method (MAM). Table 4 presents the advantages and limitations of the methods mentioned above.

DAM is a way to identify the source of airborne microorganisms. This method can identify the specific source of microorganisms and further calculate the contribution of various sources to airborne microorganisms. Based on BLAST (Basic Local Alignment Search Tool) searches and MetaMetaDB analysis in DAM, Uetake et al. (2019) determined what fraction of airborne bacteria originated from the Pacific Ocean, providing a basis for deciding the long-distance transport of microorganisms. By using the Global Catalogue of Microorganisms (GCM) database, Fan et al. (2017) calculated the source distribution of microorganisms in the air of the Beijing subway. However, this approach does not reflect the specific relationship between the microorganisms and the local potential source contribution.

To judge the relationship between different potential sources and airborne microorganisms, CAM, another method, has also been used by several researchers (Bowers et al., 2013; Lu et al., 2018). This method requires microbiological samples such as potential sources (soil, leaves, etc.) around the sampling site. It primarily determines which one or several potential sources contribute more to airborne microorganisms by calculating the correlation between air samples and the microbial community composition of spatially co-located potential sources, based on the principal component analysis (PCA). Bowers et al. (2011a) employed this method to find that the bacterial community on the leaf surface closely resembled the bacterial community in the air. However, this method cannot accurately reflect the contribution rate of potential sources.

To further obtain the rate of contribution potential sources to the airborne microorganisms, Knights et al. (2011) developed Source Tracker Method (STM), a new model analysis method (MAM). STM is a Bayesian-based method used to identify pollution sources and pollution proportions in a marker gene and functional metagenomics studies. The main features of STM include its ability to directly estimate the source proportions and uncertainties in both known and unknown source environments. Uetake et al. (2019) employed STM to analyze the sources of bacteria over Tokyo, Japan. In China, Qi et al. (2020) identified the contribution of potential local sources of fungi in the air and found that the contribution of the leaf surfaces exceeded that of soil. Similar results were also obtained for the bacterial source analysis (Mu et al., 2020). Since the STM algorithm can provide the contribution rate, it makes up for the shortage of principal component analysis. The results of this model also reveal that the sources of some microorganisms are not from the collected samples, but from long-distance transport.

\subsection{Source identification results}

Microorganisms in the air mainly consist of fungi and bacteria, some of which cause diseases in humans and plants. The results of the research carried out using existing source identification methods suggest that the local sources of fungi and bacteria in the air mainly included soil and leaf surfaces (Bowers et al., 2011a; Bowers et al., 2011b; Bowers et al., 2013; Lymperopoulou et al., 2016; Fan et al., 2019; Qi et al., 2020). Another major source might be from the long-distance transport of bacteria and fungi (Maki et al., 2018; Šantl-Temkiv et al., 2018; Uetake et al., 2019; $\mathrm{Mu}$ et al., 2020). Moreover, each source contributed differently to bioaerosols.

Table 5 summarizes the potential sources of airborne

Table 4 Advantages and limitations of various source identification methods

\begin{tabular}{|c|c|c|c|}
\hline $\begin{array}{l}\text { Source Identification } \\
\text { Method }\end{array}$ & Main Content & Advantage & Limitation \\
\hline Database Analysis Method & $\begin{array}{c}\text { BLAST searches; } \\
\text { MetametaDB; } \\
\text { Global Catalogue of } \\
\text { Microorganisms (GCM) database }\end{array}$ & $\begin{array}{c}\text { No need to collect samples from potential } \\
\text { sources; } \\
\text { Accurate microbial sources; } \\
\text { Further analysis of various source } \\
\text { contribution rates }\end{array}$ & $\begin{array}{l}\text { Unknown relationship to local sources; } \\
\text { Need of long time and a lot of work }\end{array}$ \\
\hline $\begin{array}{l}\text { Correlation Analysis } \\
\text { Method }\end{array}$ & $\begin{array}{l}\text { Principal component analysis } \\
\text { (PCA) }\end{array}$ & $\begin{array}{l}\text { Known relationship to local sources; } \\
\text { Easy to operate }\end{array}$ & $\begin{array}{l}\text { Need to collect samples from potential sources } \\
\text { and identify microbial communities; } \\
\text { Unable to determine the contribution rate of } \\
\text { local sources }\end{array}$ \\
\hline Model Analysis Method & Source Tracker & $\begin{array}{c}\text { Determining the contribution rate of local } \\
\text { sources; } \\
\text { Easy to operate }\end{array}$ & $\begin{array}{c}\text { Need to collect samples from potential sources } \\
\text { and identify microbial communities; } \\
\text { Limited to collected source samples; } \\
\text { Calculation error }\end{array}$ \\
\hline
\end{tabular}


Table 5 Distribution of bacterial sources in different regions worldwide

\begin{tabular}{|c|c|c|c|c|c|}
\hline Region & Time & Environmental sample & Analysis method & Source distribution & Reference \\
\hline Tokyo, Japan & $2016.8-2017.2$ & Soil; Bay; River; Pond & SourceTracker2 & $\begin{array}{l}\text { Summer: } \text { bay }>\text { soil }>\text { river }>\text { pond } \\
\text { Autumn: } \text { soil }>\text { river }>\text { bay }>\text { pond } \\
\text { Winter: } \text { bay }>\text { soil }>\text { river }>\text { pond }\end{array}$ & $\begin{array}{l}\text { Uetake et al., } \\
2019\end{array}$ \\
\hline Mayville, USA & & & & $\begin{array}{c}\text { Summer: feces }>\text { leaf surface }> \\
\quad \text { soil } \\
\text { Winter: feces }>\text { leaf surface }>\text { soil }\end{array}$ & $\begin{array}{l}\text { Bowers et al., } \\
2011 \mathrm{~b}\end{array}$ \\
\hline Chicago, USA & & & & $\begin{array}{l}\text { Summer: feces }>\text { soil }>\text { leaf sur } \\
\text { face }\end{array}$ & \\
\hline Detroit, USA & $\begin{array}{l}2007 \text { (min-summer; } \\
\text { min-winter) }\end{array}$ & $\begin{array}{l}\text { Soil; } \\
\text { Leaf surface; } \\
\text { Feces }\end{array}$ & $\begin{array}{l}\text { A procedure to calculate } \\
\text { different source } \\
\text { contributions }\end{array}$ & $\begin{array}{l}\text { Winter: feces }>\text { soil }>\text { leaf surface } \\
\text { Summer: } \text { soil }>\text { feces }>\text { leaf sur- } \\
\text { face } \\
\text { Winter: feces }>\text { soil }>\text { leaf surface }\end{array}$ & \\
\hline $\begin{array}{l}\text { Cleveland, } \\
\text { USA }\end{array}$ & & & & $\begin{array}{c}\begin{array}{c}\text { Summer: soil }>\text { leaf surface }>- \\
\text { feces }\end{array} \\
\text { Winter: feces }>\text { soil }>\text { leaf surface }\end{array}$ & \\
\hline Xi'an, China & 2017 (autumn; winter) & $\begin{array}{c}\text { Soil; } \\
\text { Leaf surface; }\end{array}$ & $\begin{array}{l}\text { A procedure to calculate } \\
\text { different source } \\
\text { contributions }\end{array}$ & $\begin{array}{c}\text { Autumn: leaf surface }>\text { soil }> \\
\text { feces } \\
\text { Winter: soil }>\text { leaf surface }>\text { feces }\end{array}$ & $\begin{array}{l}\text { Fan et al., } \\
2019\end{array}$ \\
\hline $\begin{array}{l}\text { Southnest } \\
\text { Greenland }\end{array}$ & $2013.7-8$ & $\begin{array}{l}\text { Soil; Plant; Snow; } \\
\text { Water; Rain }\end{array}$ & Correlation analysis & $\begin{array}{l}\text { Major: soil, decaying vegetation, } \\
\text { long-range transport }\end{array}$ & $\begin{array}{c}\text { Šantl-Temkiv et al., } \\
2018\end{array}$ \\
\hline
\end{tabular}

microorganisms in published references based on the aforementioned source identification methods. The arctic air was found to contain a rich diversity of bacteria, which were likely from a local land environment (mainly soil and rotting vegetation) or through long-distance transport into the arctic atmospheric boundary layer (Smets et al., 2016). Near the coast of Tokyo, Japan, bioaerosols had long received local inputs of soil and seawater from the Tokyo bay (Uetake et al., 2019). Snow samples collected from the mountains indicated that local air microorganisms were significantly affected by long-distance transport (Maki et al., 2018). According to a study by Bowers et al. (2011b), the dominant sources of bacteria in cities in the Midwest of USA were different in summer and winter because the contribution rate of the soil, water, and plants significantly decreased in winter, while the contribution rate of animal feces increased (Bowers et al., 2011b).

Figure 7 shows our recent source identification results of airborne bacteria and fungi in Xi' an, China, based on the STM model. The results demonstrate that the microorganisms in the air mainly came from leaf surfaces. In addition, differences in microbial sources were observed at different sampling sites. Qi et al. (2020) and $\mathrm{Mu}$ et al. (2020) indicated that the contribution of leaf surfaces to the bioaerosol loading was higher in mountainous areas than in urban areas, which might be due to different plant species and land cover area. Fan et al. (2019) also showed that airborne pathogens were affected by potential local sources, mainly from leaf surfaces in autumn. Therefore, the influence of plant types on the sources of airborne microorganism merits further investigation.

As discussed earlier, several methods exist to determine the significant sources of bioaerosols. The analysis of microbial sources is beneficial to assess and control microbial pollution. Therefore, it is necessary to further develop more precise methods of microbial source

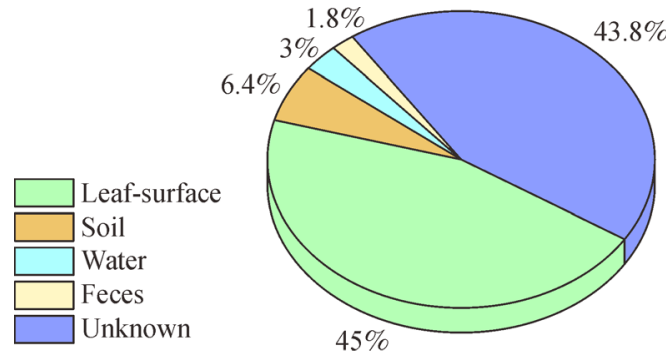

(a) Bacteria

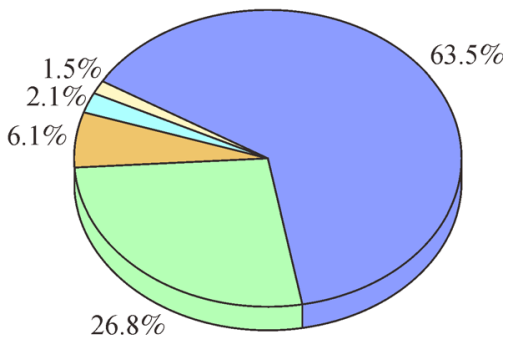

(b) Fungi

Fig. 7 The sources of bacteria and fungi in Xi'an, China. (a) The contribution of different sources to the airborne bacterial loading; (b) The contribution of various sources to airborne fungi. 
identification to uncover the contribution of various potential sources of microorganisms in the air. Biomarkers such as proteins, amino acids, carbohydrates, and lipids have been recently applied to aid the identification of aerosol sources and study the aerosol transport trajectory (Hu et al., 2020). Besides, the influence of the chemical components in aerosols on the source distribution of airborne microorganisms remains unclear. This factor should be considered in the development of novel source identification methods.

\section{Conclusions and perspectives}

The knowledge of sources and transport of bioaerosols is of crucial importance to better understand the role of microorganisms in the atmosphere and control the spread of epidemic diseases associated with bioaerosols. Over the past two decades, significant progress has been made on the source characteristics, source identification, and diffusion and transport modeling of bioaerosols. However, some vital scientific questions on bioaerosols remain unaddressed so far.

The existing studies on bioaerosols focused primarily on the changes in microbial concentration and community structure. However, future research should dive into the emission characteristics (emission flux) of bioaerosols from various sources, especially from artificial sources. This can provide a sound basis for estimating bioaerosol emissions, transport, and their impact on the atmosphere and public health.

The diffusion and transport models can immensely help to improve the understanding of the transport process of bioaerosols and their influencing factors. Therefore, more accurate comprehensive models that consider the emission and biochemical properties of microorganisms and their possible changes in the atmosphere are required in the future.

The interactions between the factors affecting the diffusion and transport of bioaerosols are incredibly complicated and are far from resolved. Hence, sophisticated statistical methods such as independent variable screening, collinear diagnosis, principal component analysis are recommended to re-integrate the potential influencing factors and thus obtain a more precise correlation between each factor and bioaerosols.

Although several statistical methods have been developed to identify the possible sources of bioaerosols, more precise techniques are still needed to uncover the contribution of various potential sources of microorganisms in the air.

Acknowledgements This study was supported by the National Natural Science Foundation of China (Grant No. 51478045), the Fund Project of Guangdong Key Laboratory of Environmental Catalysis and Health Risk Control (GKECHRC-07), the Fund Project of Shaanxi Key Laboratory of
Land Consolidation (2018-ZD04), and the Opening Fund of State Key Laboratory of Green Building in Western China (LSKF202008).

\section{References}

Abd Aziz A, Lee K, Park B, Park H, Park K, Choi I G, Chang I S (2018). Comparative study of the airborne microbial communities and their functional composition in fine particulate matter $\left(\mathrm{PM}_{2.5}\right)$ under nonextreme and extreme $\mathrm{PM}_{2.5}$ conditions. Atmospheric Environment, 194: 82-92

Alves D A, Glynn A R, Steele K E, Lackemeyer M G, Garza N L, Buck J G, Mech C, Reed D S (2010). Aerosol exposure to the Angola Strain of Marburg Virus causes lethal viral hemorrhagic fever in cynomolgus macaques. Veterinary Pathology, 47(5): 831-851

Amato P, Joly M, Schaupp C, Attard E, Mohler O, Morris C E, Brunet Y, Delort A M (2015). Survival and ice nucleation activity of bacteria as aerosols in a cloud simulation chamber. Atmospheric Chemistry and Physics, 15(11): 6455-6465

Anglada J M, Martins-Costa M, Francisco J S, Ruiz-Lopez M F (2015). Interconnection of reactive oxygen species chemistry across the interfaces of atmospheric, environmental, and biological processes. Accounts of Chemical Research, 48(3): 575-583

Ansari T U, Valsan A E, Ojha N, Ravikrishna R, Narasimhan B, Gunthe S S (2015). Model simulations of fungal spore distribution over the Indian region. Atmospheric Environment, 122: 552-560

Asadi S, Bouvier N, Wexler A S, Ristenpart W D (2020). The coronavirus pandemic and aerosols: Does COVID-19 transmit via expiratory particles? Aerosol Science and Technology, 54(6): 635638

Balyan P, Das S, Ghosh C, Baneriee B D (2017). Spatial variation of biogenic aerosols at different land use configurations in urban delhi. International Journal of Applied Environmental Sciences, 12(5(1)): 731-744

Balyan P, Ghosh C, Das S, Banerjee B D (2020). Spatio-temporal characterisation of bioaerosols at diverse outdoor land-use sites in an urban environment. Aerobiologia, 36(1): 77-81

Barberan A, Dunn R R, Reich B J, Pacifici K, Laber E B, Menninger H L, Morton J M, Henley J B, Leff J W, Miller S L, Fierer N (2015a). The ecology of microscopic life in household dust. Proceedings of the Royal Society B-Biological Sciences, 282(1814): 212-220

Barberan A, Ladau J, Leff J W, Pollard K S, Menninger H L, Dunn R R, Fierer N (2015b). Continental-scale distributions of dust-associated bacteria and fungi. Proceedings of the National Academy of Sciences of the United States of America, 112(18): 5756-5761

Barnaba F, Bolignano A, Di Liberto L, Morelli M, Lucarelli F, Nava S, Perrino C, Canepari S, Basart S, Costabile F, Dionisi D, Ciampichetti S, Sozzi R, Gobbi G P (2017). Desert dust contribution to $\mathrm{PM}_{10}$ loads in Italy: Methods and recommendations addressing the relevant European Commission Guidelines in support to the Air Quality Directive 2008/50. Atmospheric Environment, 161: 288-305

Bauer H, Giebl H, Hitzenberger R, Kasper-Giebl A, Reischl G, Zibuschka F, Puxbaum H (2003). Airborne bacteria as cloud condensation nuclei. Journal of Geophysical Research, 108(D21): 
AAC2-1-AAC2-AAC2-5

Bowers R M, Clements N, Emerson J B, Wiedinmyer C, Hannigan M P, Fierer N (2013). Seasonal variability in bacterial and fungal diversity of the near-surface atmosphere. Environmental Science \& Technology, 47(21): 12097-12106

Bowers R M, Mcletchie S, Knight R, Fierer N (2011a). Spatial variability in airborne bacterial communities across land-use types and their relationship to the bacterial communities of potential source environments. ISME Journal, 5(4): 601-612

Bowers R M, Sullivan A P, Costello E K, Collett J L Jr, Knight R, Fierer N (2011b). Sources of bacteria in outdoor air across cities in the midwestern United States. Applied and Environmental Microbiology, 77(18): 6350-6356

Bui V N, Nguyen T T, Hung N V, Bui A N, Mccallion K A, Lee H S, Than S T, Coleman K K, Gray G C (2019). Bioaerosol sampling to detect avian influenza virus in Hanoi's largest live poultry market. Clinical Infectious Diseases, 68(6): 972-975

Burrows S M, Butler T, Jöckel P, Tost H, Kerkweg A, Pöschl U, Lawrence M G (2009a). Bacteria in the global atmosphere - part 2: modeling of emissions and transport between different ecosystems. Atmospheric Chemistry and Physics, 9(23): 9281-9297

Burrows S M, Elbert W, Lawrence M G, Pöschl U (2009b). Bacteria in the global atmosphere - part 1: review and synthesis of literature data for different ecosystems. Atmospheric Chemistry and Physics, 9(23): 9263-9280

Burrows S M, Rayner P J, Butler T, Lawrence M G (2013). Estimating bacteria emissions from inversion of atmospheric transport: sensitivity to modelled particle characteristics. Atmospheric Chemistry and Physics, 13(11): 5473-5488

Cáliz J, Triadó-Margarit X, Camarero L, Casamayor E O (2018). A longterm survey unveils strong seasonal patterns in the airborne microbiome coupled to general and regional atmospheric circulations. Proceedings of the National Academy of Sciences of the United States of America, 115(48): 12229-12234

Cha S, Lee D, Jang J H, Lim S, Yang D, Seo T (2016). Alterations in the airborne bacterial community during Asian dust events occurring between February and March 2015 in Korea. Scientific Reports, 6(1): 37271

Chao J, Mu X, Xue Y, Li F, Li W, Lin C H, Pei J, Chen Q (2014). A modified tracer-gas decay model for ventilation rate measurements in long and narrow spaces. Indoor and Built Environment, 23(7): 10121020

Chi X L, Tang Z Y, Fang J Y (2014). Patterns of phylogenetic beta diversity in China's grasslandsin in relation to geographical and environmental distance. Basic and Applied Ecology, 15(5): 416-425

Cho B C, Hwang C Y (2011). Prokaryotic abundance and 16S rRNA gene sequences detected in marine aerosols on the East Sea (Korea). FEMS Microbiology Ecology, 76(2): 327-341

Costello E K, Lauber C L, Hamady M, Fierer N, Gordon J I, Knight R (2009). Bacterial community variation in human body habitats across space and time. Science, 326(5960): 1694-1697

Dai P, Shen D, Tang Q, Huang K, Li C (2020). $\mathrm{PM}_{2.5}$ from a broiler breeding production system: The characteristics and microbial community analysis. Environmental Pollution, 256: 113368

Degois J, Clerc F, Simon X, Bontemps C, Leblond P, Duquenne P (2017). First metagenomic survey of the microbial diversity in bioaerosols emitted in waste sorting plants. Annals of Work Exposures and Health, 61(9): 1076-1086

Després V, Huffman J A, Burrows S M, Hoose C, Safatov A, Buryak G, Fröhlich-Nowoisky J, Elbert W, Andreae M, Pöschl U, Jaenicke R (2012). Primary biological aerosol particles in the atmosphere: a review. Tellus B. Chemical and Physical Meteorology, 64(1): 15598

Després V, Nowoisky J, Klose M, Conrad R, Pöschl U (2007). Molecular genetics and diversity of primary biogenic aerosol particles in urban, rural, and high-alpine air. Biogeosciences Discussions, 4(1): 349-384

Du P, Du R, Ren W, Lu Z, Fu P (2018). Seasonal variation characteristic of inhalable microbial communities in PM2.5 in Beijing city, China. Science of the Total Environment, 610-611: 308-315

El Jarroudi M, Karjoun H, Kouadio L, El Jarroudi M (2020). Mathematical modelling of non-local spore dispersion of windborne pathogens causing fungal diseases. Applied Mathematics and Computation, 376: 125107

Estillore A D, Trueblood J V, Grassian V H (2016). Atmospheric chemistry of bioaerosols: heterogeneous and multiphase reactions with atmospheric oxidants and other trace gases. Chemical Science (Cambridge), 7(11): 6604-6616

Fan C, Li Y, Liu P, Mu F, Xie Z, Lu R, Qi Y, Wang B, Jin C (2019). Characteristics of airborne opportunistic pathogenic bacteria during autumn and winter in Xi'an, China. Science of the Total Environment, 672: 834-845

Fan H, Li X, Deng J, Da G, Gehin E, Yao M (2017). Time-dependent sze-resolved bacterial and fungal aerosols in Beijing subway. Aerosol and Air Quality Research, 17(3): 799-809

Fraczek K, Kozdrój J, Górny R L, Cyprowski M, Golofit-Szymczak M (2017). Fungal air contamination in distinct sites within a municipal landfill area. International Journal of Environmental Science and Technology, 14(12): 2637-2648

Fröhlich-Nowoisky J, Kampf C J, Weber B, Huffman J A, Pöhlker C, Andreae M O, Lang-Yona N, Burrows S M, Gunthe S S, Elbert W, Su H, Hoor P, Thines E, Hoffmann T, Després V R, Pöschl U (2016). Bioaerosols in the Earth system: Climate, health, and ecosystem interactions. Atmospheric Research, 182: 346-376

Garrison V H, Majewski M S, Foreman W T, Genualdi S A, Mohammed A, Simonich S L M (2014). Persistent organic contaminants in Saharan dust air masses in West Africa, Cape Verde and the eastern Caribbean. Science of the Total Environment, 468-469: 530-543

Garza A G, Van Cuyk S M, Brown M J, Omberg K M (2014). Detection of the urban release of a bacillus anthracis simulant by air sampling. Biosecurity and Bioterrorism, 12(2): 66-75

Genitsaris S, Stefanidou N, Katsiapi M, Kormas K A, Sommer U, Moustaka-Gouni M (2017). Variability of airborne bacteria in an urban Mediterranean area (Thessaloniki, Greece). Atmospheric Environment, 157: 101-110

Ghanizadeh F, Godini H (2018). A review of the chemical and biological pollutants in indoor air in hospitals and assessing their effects on the health of patients, staff and visitors. Reviews on Environmental Health, 33(3): 231-245

Gopalakrishnan S, Arigela R, Gupta S K, Raghunathan R (2019). Dynamic response of passive release of fungal spores from exposure to air. Journal of Aerosol Science, 133: 37-48

Gou H, Lu J, Li S, Tong Y, Xie C, Zheng X (2016). Assessment of 
microbial communities in $\mathrm{PM}_{1}$ and $\mathrm{PM}_{10}$ of Urumqi during winter. Environmental Pollution, 214: 202-210

Hagerman A D, South D D, Sondgerath T C, Patyk K A, Sanson R L, Schumacher R S, Delgado A H, Magzamen S (2018). Temporal and geographic distribution of weather conditions favorable to Check 1 airborne spread of foot-and-mouth disease in the coterminous United States. Preventive Veterinary Medicine, 161: 41-49

Han H J, Wen H L, Zhou C M, Chen F F, Luo L M, Liu J W, Yu X J (2015). Bats as reservoirs of severe emerging infectious diseases. Virus Research, 205: 1-6

Hoose C, Kristjansson J E, Burrows S M (2010). How important is biological ice nucleation in clouds on a global scale? Environmental Research Letters, 5(2): 024009

Hospodsky D, Yamamoto N, Nazaroff W W, Miller D, Gorthala S, Peccia J (2015). Characterizing airborne fungal and bacterial concentrations and emission rates in six occupied children's classrooms. Indoor Air, 25(6): 641-652

Hsiao T C, Lin A Y C, Lien W C, Lin Y C (2020). Size distribution, biological characteristics and emerging contaminants of aerosols emitted from an urban wastewater treatment plant. Journal of Hazardous Materials, 388: 121809

Hu W, Murata K, Fukuyama S, Kawai Y, Oka E, Uematsu M, Zhang D (2017). Concentration and viability of airborne bacteria over the kuroshio extension region in the northwestern Pacific Ocean: data from three cruises. Journal of Geophysical Research, D, Atmospheres, 122(23): 12891-12905

Hu W, Wang Z, Huang S, Ren L, Yue S, Li P, Xie Q, Zhao W, Wei L, Ren H, Wu L, Deng J, Fu P (2020). Biological aerosol particles in polluted regions. Current Pollution Reports, 6(2): 65-89

Hummel M, Hoose C, Gallagher M, Healy D A, Huffman J A, O'connor D, Poschl U, Pohlker C, Robinson N H, Schnaiter M, Sodeau J R, Stengel M, Toprak E, Vogel H (2015). Regional-scale simulations of fungal spore aerosols using an emission parameterization adapted to local measurements of fluorescent biological aerosol particles. Atmospheric Chemistry and Physics, 15(11): 6127-6146

Jahne M A, Rogers S W, Holsen T M, Grimberg S J, Ramler I P, Kim S (2016). Bioaerosol deposition to food crops near manure application: Quantitative microbial risk assessment. Journal of Environmental Quality, 45(2): 666-674

Jones A M, Harrison R M (2004). The effects of meteorological factors on atmospheric bioaerosol concentrations - a review. Science of the Total Environment, 326(1/3): 151-180

Joung Y S, Ge Z F, Buie C R (2017). Bioaerosol generation by raindrops on soil. Nature Communications, 8(1): 14668

Kang S M, Heo K J, Lee B U (2015). Why does rain increase the concentrations of environmental bioaerosols during monsoon? Aerosol and Air Quality Research, 15(6): 2320-2324

Kim K H, Kabir E, Jahan S A (2018). Airborne bioaerosols and their impact on human health. Journal of Environmental Sciences-China, 67: $23-35$

Knights D, Kuczynski J, Charlson E S, Zaneveld J, Mozer M C, Collman R G, Bushman F D, Knight R, Kelley S T (2011). Bayesian community-wide culture-independent microbial source tracking. Nature Methods, 8(9): 761-763

Kowalski M, Pastuszka J S (2018). Effect of ambient air temperature and solar radiation on changes in bacterial and fungal aerosols concentration in the urban environment. Annals of Agricultural and Environmental Medicine, 25(2): 259-261

Kowalski M, Wolany J, Pastuszka J S, Plaza G, Wlazlo A, Ulfig K, Malina A (2017). Characteristics of airborne bacteria and fungi in some Polish wastewater treatment plants. International Journal of Environmental Science and Technology, 14(10): 2181-2192

Kumari P, Woo C, Yamamoto N, Choi H L (2016). Variations in abundance, diversity and community composition of airborne fungi in swine houses across seasons. Scientific Reports, 6(1): 37929

Lee I, Bitog J P P, Hong S W, Seo I H, Kwon K S, Bartzanas T, Kacira M (2013). The past, present and future of CFD for agro-environmental applications. Computers and Electronics in Agriculture, 93: 168-183

Li W, Yang J, Zhang D, Li B, Wang E, Yuan H (2018). Concentration and community of airborne bacteria in response to cyclicalhaze events during the fall and midwinter in Beijing, China. Frontiers in Microbiology, 9: 12

Lin Y, Xiangdong L, Yihuan Y, Jiyuan T (2018). Effects of cough-jet on airflow and contaminant transport in an airliner cabin section. Journal of Computational Multiphase Flows, 10(2): 72-82

Lindsley W G, Blachere F M, Thewlis R E, Vishnu A, Davis K A, Cao G, Palmer J E, Clark K E, Fisher M A, Khakoo R, Beezhold D H (2010). Measurements of airborne influenza virus in aerosol particles from human coughs. PLoS One, 5(11): e15100

Lu R, Li Y P, Li W X, Xie Z S, Fan C L, Liu P X, Deng S X (2018). Bacterial community structure in atmospheric particulate matters of different sizes during the haze days in Xi'an, China. Science of the Total Environment, 637-638: 244-252

Luckey D T (1972). Introduction to intestinal microecology. American Journal of Clinical Nutrition, 25(12): 1292-1294

Lymperopoulou D S, Adams R I, Lindow S E (2016). Contribution of vegetation to the microbial composition of nearby outdoor air. Applied and Environmental Microbiology, 82(13): 3822-3833

Ma J, Qi X, Chen H, Li X, Zhang Z, Wang H, Sun L, Zhang L, Guo J, Morawska L, Grinshpun S A, Biswas P, Flagan R C, Yao M (2020). COVID-19 patients in earlier stages exhaled millions of SARS-CoV2 per hour. Clinical Infectious Diseases, ciaa1283

Ma M, Zhen Y, Mi T (2019). Characterization of bacterial communities in bioaerosols over northern chinese marginal seas and the northwestern Pacific Ocean in spring. Journal of Applied Meteorology and Climatology, 58(4): 903-917

Makhalanyane T P, Valverde A, Gunnigle E, Frossard A, Ramond J B, Cowan D A (2015). Microbial ecology of hot desert edaphic systems. FEMS Microbiology Reviews, 39(2): 203-221

Maki T, Furumoto S, Asahi Y, Lee K C, Watanabe K, Aoki K, Murakami M, Tajiri T, Hasegawa H, Mashio A, Iwasaka Y (2018). Long-rangetransported bioaerosols captured in snow cover on Mount Tateyama, Japan: impacts of Asian-dust events on airborne bacterial dynamics relating to ice-nucleation activities. Atmospheric Chemistry and Physics, 18(11): 8155-8171

Martin E, Kampfer P, Jackel U (2010). Quantification and identification of culturable airborne bacteria from duck houses. Annals of Occupational Hygiene, 54(2): 217-227

Matthias-Maser S, Jaenicke R (1995). The size distribution of primary biological aerosol particles with radii $>0.2 \mu \mathrm{m}$ in an urban /rural influenced region. Atmospheric Research, 39(4): 279-286

McEachran A D, Blackwell B R, Hanson J D, Wooten K J, Mayer G D, 
Cox S B, Smith P N (2015). Antibiotics, bacteria, and antibiotic resistance genes: aerial transport from cattle feed yards via particulate matter. Environmental Health Perspectives, 123(4): 337-343

Mhuireach G, Johnson B R, Altrichter A E, Ladau J, Meadow J F, Pollard K S, Green J L (2016). Urban greenness influences airborne bacterial community composition. Science of the Total Environment, 571: $680-687$

Michalkiewicz M (2019). Wastewater treatment plants as a source of bioaerosols. Polish Journal of Environmental Studies, 28(4): 22612271

Mu F F, Li Y P, Lu R, Qi Y Z, Xie W W, Bai W Y (2020). Source identification of airborne bacteria in the mountainous area and the urban areas. Atmospheric Research, 231: 104676

Murata K, Zhang D Z (2016). Concentration of bacterial aerosols in response to synoptic weather and land-sea breeze at a seaside site downwind of the Asian continent. Journal of Geophysical Research, D, Atmospheres, 121(19): 11636-11647

Nemergut D R, Costello E K, Hamady M, Lozupone C, Jiang L, Schmidt S K, Fierer N, Townsend A R, Cleveland C C, Stanish L, Knight R (2011). Global patterns in the biogeography of bacterial taxa. Environmental Microbiology, 13(1): 135-144

Nguyen T, Yu X X, Zhang Z M, Liu M M, Liu X H (2015). Relationship between types of urban forest and $\mathrm{PM}_{2.5}$ capture at three growth stages of leaves. Journal of Environmental Sciences-China, 27: 3341

Núñez A, Amo De Paz G, Rastrojo A, Ferencova Z, Gutiérrez-Bustillo A M, Alcamí A, Moreno D A, Guantes R (2019). Temporal patterns of variability for prokaryotic and eukaryotic diversity in the urban air of Madrid (Spain). Atmospheric Environment, 217: 116972

Oduber F, Calvo A I, Blanco-Alegre C, Castro A, Nunes T, Alves C, Sorribas M, Feraandez-Gonzalez D, Vega-Maray A M, ValenciaBarrera R M, Lucarelli F, Nava S, Calzolai G, Alonso-Blanco E, Fraile B, Fialho P, Coz E, Prevot A S H, Pont V, Fraile R (2019). Unusual winter Saharan dust intrusions at Northwest Spain: Air quality, radiative and health impacts. Science of the Total Environment, 669: 213-228

Pagalilauan H a M, Paraoan C E M, Vital P G (2018). Detection of pathogenic bioaerosols and occupational risk in a Philippine landfill site. Archives of Environmental \& Occupational Health, 73(2): 107114

Pellissier L, Oppliger A, Hirzel A H, Savova-Bianchi D, Mbayo G, Mascher F, Kellenberger S, Niculita-Hirzel H (2016). Airborne and grain dust fungal community compositions are shaped regionally by plant genotypes and farming practices. Applied and Environmental Microbiology, 82(7): 2121-2131

Poschl U, Shiraiwa M (2015). Multiphase chemistry at the atmospherebiosphere interface influencing climate and public health in the anthropocene. Chemical Reviews, 115(10): 4440-4475

Qi Y Z, Li Y P, Xie W W, Lu R, Mu F F, Bai W Y, Du S L (2020). Temporal-spatial variations of fungal composition in $\mathrm{PM}_{2.5}$ and source tracking of airborne fungi in mountainous and urban regions. Science of the Total Environment, 708: 135027

Redford A J, Bowers R M, Knight R, Yan L, Fierer N (2010). The ecology of the phyllosphere: geographic and phylogenetic variability in the distribution of bacteria on tree leaves. Environmental Microbiology, 12(11): 2885-2893
Rodo X, Ballester J, Cayan D, Melish M E, Nakamura Y, Uehara R, Burns J C (2011). Association of Kawasaki disease with tropospheric wind patterns. Scientific Reports, 1(1): 152

Runlan Y, Shuokun W, Xueling W, Li S, Yuandong L, Jiaokun L, Guanzhou Q, Weimin Z (2019). Community structure variation associated with airborne particulate matter at central south of China during hazy and nonhazy days. Atmospheric Pollution Research, 10 (5): 1536-1542

Šantl-Temkiv T, Gosewinkel U, Starnawski P, Lever M, Finster K (2018). Aeolian dispersal of bacteria in southwest Greenland: their sources, abundance, diversity and physiological states. FEMS Microbiology Ecology, 94(4):1-10

Sesartic A, Lohmann U, Storelvmo T (2012). Bacteria in the ECHAM5HAM global climate model. Atmospheric Chemistry and Physics, 12 (18): 8645-8661

Sialve B, Gales A, Hamelin J, Wery N, Steyer J P (2015). Bioaerosol emissions from open microalgal processes and their potential environmental impacts: what can be learned from natural and anthropogenic aquatic environments? Current Opinion in Biotechnology, 33: 279-286

Skora J, Matusiak K, Wojewodzki P, Nowak A, Sulyok M, Ligocka A, Okrasa M, Hermann J, Gutarowska B (2016). Evaluation of microbiological and chemical contaminants in poultry farms. International Journal of Environmental Research and Public Health, 13(2): 192

Smets W, Moretti S, Denys S, Lebeer S (2016). Airborne bacteria in the atmosphere: Presence, purpose, and potential. Atmospheric Environment, 139: 214-221

Stein A F, Draxler R R, Rolph G D, Stunder B J B, Cohen M D, Ngan F (2015). NOAA's HYSPLIT atmospheric transport and dispersion modeling system. Bulletin of the American Meteorological Society, 96(12): 2059-2077

Stockwell R E, Ballard L, O'rourke P, Knibbs L D, Morawska L, Bell S C (2019). Indoor hospital air and the impact of ventilation on bioaerosols: a systematic review. Journal of Hospital Infection, 103 (2): 175-184

Szylak-Szydlowski M, Kulig A, Miaśkiewicz-Peska E (2016). Seasonal changes in the concentrations of airborne bacteria emitted from a large wastewater treatment plant. International Biodeterioration \& Biodegradation, 115: 11-16

Tanaka D, Sato K, Goto M, Fujiyoshi S, Maruyama F, Takato S, Shimada T, Sakatoku A, Aoki K, Nakamura S (2019). Airborne microbial communities at high-altitude and suburban sites in Toyama, Japan Suggest a new perspective for bioprospecting. Frontiers in Bioengineering and Biotechnology, 7: 12

Tang J W (2009). The effect of environmental parameters on the survival of airborne infectious agents. Journal of the Royal Society, Interface, 6(Suppl 6): S737-S746

Tang K, Huang Z, Huang J, Maki T, Zhang S, Shimizu A, Ma X, Shi J, Bi J, Zhou T, Wang G, Zhang L (2018). Characterization of atmospheric bioaerosols along the transport pathway of Asian dust during the Dust-Bioaerosol 2016 Campaign. Atmospheric Chemistry and Physics, 18(10): 7131-7148

Thatiparti D S, Ghia U, Mead K R (2017). Computational fluid dynamics study on the influence of an alternate ventilation configuration on the possible flow path of infectious cough aerosols in a mock airborne 
infection isolation room. Science and Technology for the Built Environment, 23(2): 355-366

Theofel C G, Williams T R, Gutierrez E, Davidson G R, Jay-Russell M, Harris L J (2020). Microorganisms move a short distance into an almond orchard from an adjacent upwind poultry operation. Applied and Environmental Microbiology, 86(15): e00573-20

Uetake J, Tobo Y, Uji Y, Hill T C J, Demott P J, Kreidenweis S M, Misumi R (2019). Seasonal changes of airborne bacterial communities over Tokyo and influence of local meteorology. Frontiers in Microbiology, 10: 1572

van Doremalen N, Bushmaker T, Morris D H, Holbrook M G, Gamble A, Williamson B N, Tamin A, Harcourt J L, Thornburg N J, Gerber S I, Lloyd-Smith J O, De Wit E, Munster V J (2020). Aerosol and surface stability of SARS-CoV-2 as compared with SARS-CoV-1. New England Journal of Medicine, 382(16): 1564-1567

Varin T, Lovejoy C, Jungblut A D, Vincent W F, Corbeil J (2012). Metagenomic analysis of stress genes in microbial mat communities from Antarctica and the High Arctic. Applied and Environmental Microbiology, 78(2): 549-559

Vejerano E P, Marr L C (2018). Physico-chemical characteristics of evaporating respiratory fluid droplets. Journal of the Royal Society, Interface, 15(139): 20170939

Veresoglou S D, Rillig M C (2014). Challenging cherished ideas in mycorrhizal ecology: the Baylis postulate. New Phytologist, 204(1): $1-3$

Vorholt J A (2012). Microbial life in the phyllosphere. Nature Reviews. Microbiology, 10(12): 828-840

Wang J M, Chen C, Li J W, Feng Y M, Lu Q (2019). Different ecological processes determined the alpha and beta components of taxonomic, functional, and phylogenetic diversity for plant communities in dryland regions of Northwest China. PeerJ, 6: e6220

Wei J J, Li Y G (2016). Airborne spread of infectious agents in the indoor environment. American Journal of Infection Control, 44(9): S102S108

White J K, Nielsen J L, Madsen A M (2019). Microbial species and biodiversity in settling dust within and between pig farms.
Environmental Research, 171: 558-567

William B W, David C C, Wiebe W J (1998). Prokaryotes: The unseen majority. Proceedings of the National Academy of Sciences of the United States of America, 95: 6578-6583

Wong L T, Chan W Y, Mui K W, Lai A C K (2010). An experimental and numerical study on deposition of bioaerosols in a scaled chamber. Aerosol Science and Technology, 44(2): 117-128

Xie Z, Fan C, Lu R, Liu P, Wang B, Du S, Jin C, Deng S, Li Y (2018). Characteristics of ambient bioaerosols during haze episodes in China: A review. Environmental Pollution, 243(Pt B): 1930-1942

Xiong J B, Liu Y Q, Lin X G, Zhang H Y, Zeng J, Hou J Z, Yang Y P, Yao T D, Knight R, Chu H Y (2012). Geographic distance and pH drive bacterial distribution in alkaline lake sediments across Tibetan Plateau. Environmental Microbiology, 14(9): 2457-2466

Xu C, Wei M, Chen J, Zhu C, Li J, Xu X, Wang W, Zhang Q, Ding A, Kan H, Zhao Z, Mellouki A (2019). Profile of inhalable bacteria in $\mathrm{PM}_{2.5}$ at Mt. Tai, China: Abundance, community, and influence of air mass trajectories. Ecotoxicology and Environmental Safety, 168: 110-119

Xu C H, Wei M H, Chen J M, Wang X F, Zhu C, Li J R, Zheng L L, Sui G D, Li W J, Wang W X, Zhang Q Z, Mellouki A (2017). Bacterial characterization in ambient submicron particles during severe haze episodes at Ji'nan, China. Science of the Total Environment, 580: 188-196

Xu G, Han Y, Li L, Liu J (2018). Characterization and source analysis of indoor/outdoor culturable airborne bacteria in a municipal wastewater treatment plant. Journal of Environmental Sciences-China, 74: 71-78

Zhang J, Li Y, Xu E, Jiang L, Tang J, Li M, Zhao X, Chen G, Zhu H, Yu $X$, Zhang $X$ (2019). Bacterial communities in $\mathrm{PM}_{2.5}$ and $\mathrm{PM}_{10}$ in broiler houses at different broiler growth stages in spring. Polish Journal of Veterinary Sciences, 22(3): 495-504

Zhen Q, Deng Y, Wang Y, Wang X, Zhang H, Sun X, Ouyang Z (2017). Meteorological factors had more impact on airborne bacterial communities than air pollutants. Science of the Total Environment, 601-602: 703-712 